\title{
Changing the Recipe: Pathogen Directed Changes in Tick Saliva Components
}

\author{
Michael Pham (D), Jacob Underwood and Adela S. Oliva Chávez *(D) \\ Department of Entomology, College Station, Texas A\&M University, TX 77843, USA; mpham@tamu.edu (M.P.); \\ jacob.underwood@tamu.edu (J.U.) \\ * Correspondence: aolivachavez@tamu.edu; Tel.: +1-979-845-1946
}

Citation: Pham, M.; Underwood, J.; Oliva Chávez, A.S. Changing the Recipe: Pathogen Directed Changes in Tick Saliva Components. Int. J. Environ. Res. Public Health 2021, 18 , 1806. https://doi.org/10.3390/ ijerph18041806

Academic Editor: Paul B. Tchounwou

Received: 15 January 2021

Accepted: 8 February 2021

Published: 12 February 2021

Publisher's Note: MDPI stays neutral with regard to jurisdictional claims in published maps and institutional affiliations.

Copyright: (c) 2021 by the authors. Licensee MDPI, Basel, Switzerland. This article is an open access article distributed under the terms and conditions of the Creative Commons Attribution (CC BY) license (https:/ / creativecommons.org/licenses/by/ $4.0 /)$.

\begin{abstract}
Ticks are obligate hematophagous parasites and are important vectors of a wide variety of pathogens. These pathogens include spirochetes in the genus Borrelia that cause Lyme disease, rickettsial pathogens, and tick-borne encephalitis virus, among others. Due to their prolonged feeding period of up to two weeks, hard ticks must counteract vertebrate host defense reactions in order to survive and reproduce. To overcome host defense mechanisms, ticks have evolved a large number of pharmacologically active molecules that are secreted in their saliva, which inhibits or modulates host immune defenses and wound healing responses upon injection into the bite site. These bioactive molecules in tick saliva can create a privileged environment in the host's skin that tick-borne pathogens take advantage of. In fact, evidence is accumulating that tick-transmitted pathogens manipulate tick saliva composition to enhance their own survival, transmission, and evasion of host defenses. We review what is known about specific and functionally characterized tick saliva molecules in the context of tick infection with the genus Borrelia, the intracellular pathogen Anaplasma phagocytophilum, and tick-borne encephalitis virus. Additionally, we review studies analyzing sialome-level responses to pathogen challenge.
\end{abstract}

Keywords: saliva-assisted transmission; Anaplasma phagocytophilum; tick-borne encephalitis; Borrelia burgdorferi; ticks; tick saliva; tick-borne diseases

\section{Introduction}

Ticks are capable of transmitting a wide variety of pathogens including viruses, bacteria, protozoans, fungi, and nematodes of medical and veterinary importance [1]. They are obligatory blood-feeding arthropods that are divided into three families: Argasidae (soft ticks), Ixodidae (hard ticks), and Nuttallielidae [2,3]. Soft ticks feed repeatedly for a short period (minutes to hours), while hard ticks feed for several days to weeks, depending on the life stage [4]. Ixodid larvae and nymphs take up to eight days to complete the bloodmeal, whereas adult females can feed for up to 12 days or longer [5]. Furthermore, unlike mosquitoes that pierce through the skin to reach blood vessels, ticks produce a feeding pool by cutting through the host skin with their chelicerae. The chelicerae extend and lacerate the epidermis, which is then followed by the insertion of the hypostome into the dermis [6], producing significant damage. The relatively long period of feeding and the type of lesion require the inhibition of host immunity and localized hemostasis.

Vertebrate skin represents a key environmental interface acting as a physical and immune barrier that is composed of two layers: Epidermis and dermis. These layers contain immune cells and effectors that together comprise a complex network of inflammatory, innate, and acquired immune defense mechanisms $[7,8]$. Keratinocytes act as sentinels detecting a pathogen associated molecules and toxins $[9,10]$. These cells interact with T cells to maintain tissue homeostasis and coordinate immune responses [11]. The wound healing response (including hemostatic plug formation, vasoconstriction, inflammation, and tissue remodeling) as well as pain and itch sensations occur in response to injury. Platelets also 
act as immune sentinels of damaged vessels. They guide neutrophils and other leukocytes to the site of extravasation and direct innate and adaptive immune responses [12,13]. Other immune cells residing in the skin such as Langerhans and dermal dendritic cells (DC) migrate to the lymph nodes and activate inflammatory and immune responses upon encountering antigens $[14,15]$. To counteract these challenges, ticks have evolved and acquired several effectors that diminish these immune and hemostatic responses.

Specifically, tick saliva delays wound healing and blood clotting as well as inflammatory responses with secreted molecules that interact with cytokines, chemokines, and growth factors $[16,17]$. Additionally, tick salivary glands release a wide number of immunomodulatory and anti-hemostatic molecules. These components maintain blood flow and reduce itching, inflammation, and immune rejection at the skin interface with the attached tick, allowing blood feeding to succeed. For example, tick saliva contains inhibitors (thought to include Angiotensin-converting enzyme (ACE) metalloproteases, endocannabinoids, adenosine, and others) that reduce pain and itching, preventing physical tick removal by the host [18-20]. Tick saliva also inhibits the migration of neutrophils [21] and macrophages [22] and can alter dendritic cell activation and function [23,24]. Through these bioactive components, tick saliva creates an immune-privileged local environment at the bite site that facilitates pathogen transmission. Therefore, it is not surprising that tick-borne pathogens take advantage of tick salivary secretions to enhance their establishment and infection. Herein, we review how tick-borne pathogens exploit and augment the immunomodulatory and regulatory properties of tick saliva, focusing specifically on B. burgdorferi, Anaplasma phagocytophilum, and tick-borne encephalitis virus (TBEV).

\section{Effect of Saliva on Pathogen Transmission}

\section{Saliva Assisted Transmission (SAT)}

Saliva-assisted transmission (SAT) has been observed with several tick-borne pathogens [3,25]. Several studies have reported enhanced vertebrate infection by tick-borne pathogens after needle injection along with salivary gland extracts (SGE) as compared to pathogens alone. Nevertheless, the mechanisms and molecules involved in this process have not been completely characterized. Only a relatively small number of salivary components associated with tick-borne pathogen transmission have been described, some of which are listed in Tables 1 and 2. Herein, we will discuss how sialostatin L and L2 enhance the transmission of A. phagocytophilum, TBEV, and B. burgdorferi. Additionally, salivation has also been associated with pathogen transmission in non-vertebrate vector-host systems such as Varroa destructor and Apis mellifera, where salivation alters hemocyte behavior as well as in plant diseases caused by whiteflies, aphids, mites, and psyllids, where vector salivation plays a role in altering host plant defenses [26-33].

Tick saliva is likely to influence pathogen acquisition. Reppert et al. [34] showed that tick feeding results in an increased number of neutrophils at the bite site of $A$. phagocytophilum infected and uninfected sheep. Interestingly, infection also appears to augment the number of neutrophils even in the absence of feeding ticks. Immunohistochemistry (IHC) experiments demonstrated the presence of infected neutrophils at the bite site. Infected neutrophils at the bite site have been previously reported in naturally infected lambs [35]. It is highly possible that components in tick saliva and the inflammation at the bite site results in the chemoattraction of these infected neutrophils. Chemoattraction of tick SGE has been shown for B. burgdorferi. This mechanism may explain the phenomenon of B. burgdorferi acquisition between co-feeding infected and uninfected ticks [36]. However, the exact molecules that facilitate this chemoattraction are not known.

Sialostatins are C1-type cysteine protease inhibitors (cystatins) that suppress the action of mammalian cathepsins [37,38]. Cathepsins L and S play important roles in major histocompatibility complex (MHC) II antigen processing and presentation by cells in the cortical epithelium of the thymus and professional antigen presenting cells (APCs), respectively [39]. These proteins also play a role in the suppression of chemokines, such as IP-10 (CXCL10), MIP-2 (CXCL2), MCP-1 (CCL2), RANTES (CCL5), LIX (CXCL5), CXCL16, MIP-1 $\beta$ (CCL4), 
and MIP-1 $\alpha$ (CCL3), and cytokines including TNFa, IL-9, IL-1 $\beta$, and IL-12 [40-43]. Sialostatin $\mathrm{L}$ decreases the activation of interferon regulatory factor 4 (IRF4) signaling in mast cells [40] and JAK/STAT signaling in DCs by diminishing phosphorylation of STAT-1 and STAT-2 [42]. Additionally, Sialostatin L dampens antigen mediated CD4+ proliferation [43]. Thus, these proteins affect both innate and adaptative immune responses, which in turn impacts pathogen colonization in the host. For example, sialostatin L2 reduces inflammasome activation by targeting caspase 1, affecting cytokine secretion and inflammatory responses during A. phagocytophilum infection [44]. Tick-borne encephalitis virus (TBEV) replication in DCs is enhanced in the presence of sialostatin L2, by diminishing the antiviral effect of IL-1 $\beta$ [42]. Likewise, these cystatins decrease DC activation after B. burgdorferi infection by interfering with Erk1/2 signaling [41]. These examples demonstrate the particular impact of these two salivary proteins on pathogen establishment. Other proteins have also been shown to positively impact pathogen transmission, with evidence to show that vector saliva can increase pathogen recruitment to the feeding site, explaining the evolutionary advantage that SAT represents for tick-borne pathogens [34].

\section{Role of Tick Salivary Components during Tick Feeding and Pathogen Transmission}

3.1. Effects on Hemostasis and Angiogenesis

Hemostasis is described as the balance of physiological processes that maintain blood flow and fluidity while preventing excessive blood loss at the site of a vascular injury [45] and is thus part of the wound healing responses. As the first step in wound healing, hemostasis includes vasoconstriction, followed by two linked processes: Primary hemostasis, which involves platelet aggregation, and secondary hemostasis, which induces the coagulation cascade. The activation of either the extrinsic or intrinsic coagulation pathways leads to the activation of Factor X. Activated Factor X (Factor Xa) eventually drives the conversion of prothrombin to thrombin. Crosslinked fibrin binds to the aggregated platelet plug, forming the thrombus, which stops bleeding. Wound restoration starts by the formation of new connective and granular tissue by a process of re-epithelization and neovascularization during angiogenesis [46].

Tick saliva promotes continuous blood flow with molecules that counteract the different hemostatic steps and processes involved in angiogenesis (Table 1). Some of these effectors include Salp14 and Iris identified in I. scapularis and I. ricinus, respectively [47,48] (Figure 1). Salp14, a $28 \mathrm{kDa}$ protein, delays blood coagulation by specifically inhibiting Factor Xa [47]. Iris, on the other hand, is a serpin (serine protease inhibitor) with anticoagulant, anti-hemostatic, and immunomodulatory properties [48]. It inhibits human leukocyte elastase (by $\sim 70 \%$ ), thrombin tissue plasminogen activator (tPA), and Factor Xa (by around $30 \%$ ). This serpin significantly delays the intrinsic coagulation pathway and fibrinolysis, affecting blood clot formation [48] and dampening wound healing responses (Figure 1).

The effects of these molecules on pathogen transmission have not been investigated, with the exception of the tick histamine release factor (tHRF) and B. burgdorferi (Table 1) [49]. Although there are few known examples of tick-borne pathogens directly exploiting tick proteins involved in delaying hemostasis and angiogenesis, it is likely that constant blood flow and delay in wound closure benefit tick-borne pathogen transmission. A list of proteins, their targets, effect, and whether they facilitate pathogen transmission experimentally is described in Table $1[47,49-80]$.

\subsection{Immunomodulatory Components: Effects on Host Defenses}

\subsubsection{Host Defense}

Part of the wound healing response is the activation of inflammation, which recruits immune cells into the site of tissue damage. Damage associated molecular patterns (DAMPs), increases in intracellular $\mathrm{Ca}++$, chemokines, and lipid mediators lead to the recruitment of immune cells, such as neutrophils, macrophages, mast cells, T cells, and other cells. These cells prevent infection and assist generating growth factors that lead 
to tissue repair [46]. Ticks have evolved several strategies to evade these host immune responses in order to ensure feeding to repletion and further development $[7,16,82-84]$. The capability of ticks to attach for a prolonged time has stimulated strong interest in investigating tick feeding. A necessary step in understanding tick feeding includes defining the molecular composition of tick saliva, which is also important for understanding the role of saliva in pathogen transmission. The use of global transcript and protein profiling, as well as comparative analyses, has led to the discovery of several molecules required for the induction and modulation of immune defenses [25]. However, while the general effects of tick-directed immunomodulation are known, the characterization of tick salivary gland molecules with regulatory functions is still relatively limited. Some of these molecules and the tick species that secrete them are identified in Table $2[16,21-24,38,42,49,68,72,85-105]$.

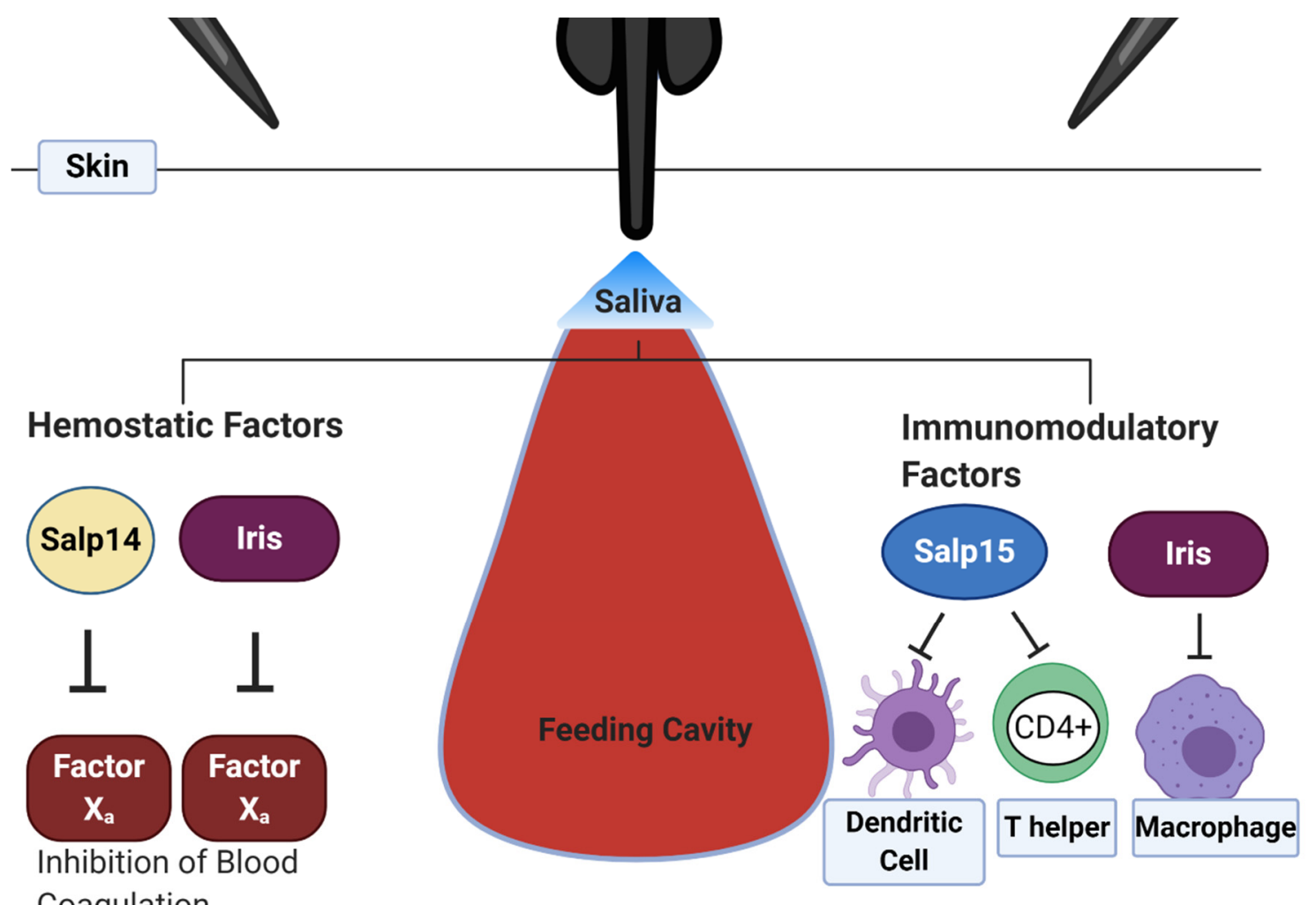

Figure 1. Secretion of anti-hemostatic (Salp14 and Iris) and immunomodulatory components (Salp15 and Iris) within tick saliva. Salp14 inhibits Factor Xa and the conversion of prothrombin to thrombin. Iris, an elastase inhibitor, hinders the intrinsic or contact-dependent coagulation pathway and platelet aggregation. The immunomodulatory protein, Salp15 prevents dendritic cell function by binding to the DC-SIGN (dendritic cell-specific intercellular adhesion molecule-3grabbing non-integrin), a lectin receptor. This binding alters dendritic cell cytokine secretion. Additionally, Salp15 binds the CD4 glycoprotein on CD4+ T-helper cells, inhibiting the T-cell receptor signaling. Iris decreases the production and secretion of pro-inflammatory IL- 6 and TNF- $\alpha$ by macrophages and affects T cell proliferation. Created with Biorender.com

Table 1. Characterized anti-hemostatic components secreted in tick saliva *.

\begin{tabular}{|c|c|c|c|c|c|}
\hline Component & Function/Activity & Target Effector/Protein & Pathogen SAT & Tick Species & References \\
\hline Apyrase & $\begin{array}{l}\text { Inhibitor of platelet } \\
\text { aggregation }\end{array}$ & $\begin{array}{l}\text { Adenosine triphospahte } \\
\text { (ATP), Adenosine } \\
\text { diphosphate (ADP) }\end{array}$ & & $\begin{array}{l}\text { Ixodes scapularis, } \\
\text { Ornithodoros savignyi }\end{array}$ & {$[73,75]$} \\
\hline $\begin{array}{l}\text { Tick histamine } \\
\text { release factor } \\
(\mathrm{tHRF})+\end{array}$ & $\begin{array}{l}\text { Binding to basophils, } \\
\text { stimulates Histamine } \\
\text { release, vasodilation }\end{array}$ & - & B. burgdorferi & $\begin{array}{l}\text { Dermacentor andersoni, I. } \\
\text { scapularis }\end{array}$ & {$[49,69]$} \\
\hline
\end{tabular}


Table 1. Cont.

\begin{tabular}{|c|c|c|c|c|c|}
\hline Component & Function/Activity & Target Effector/Protein & Pathogen SAT & Tick Species & References \\
\hline Metalloproteases & $\begin{array}{c}\text { Wound } \\
\text { healing/angiogenesis }\end{array}$ & Fibrin & & Ixodes ricinus & [56] \\
\hline Haemangin & $\begin{array}{c}\text { Wound } \\
\text { healing/angiogenesis }\end{array}$ & $\begin{array}{l}\text { Trypsin, chymotrypsin, } \\
\text { plasmin }\end{array}$ & & Haemaphysalis longicornis & [62] \\
\hline HLTnl & $\begin{array}{c}\text { Wound } \\
\text { healing/angiogenesis }\end{array}$ & $\begin{array}{l}\text { Competitive inhibitor of } \\
\text { Vascular endothelial growth } \\
\text { factor (VEGF) for VEGF } \\
\text { receptor }\end{array}$ & & H. longicornis & [60] \\
\hline PGE2 † & $\begin{array}{c}\text { Wound } \\
\text { healing/angiogenesis }\end{array}$ & $\begin{array}{c}\mathrm{PGE}_{2} \text { receptor, cyclic } \\
\text { Adenosine monophosphate } \\
\text { (AMP)-proteins kinase A } \\
\text { (cAMP-PKA) }\end{array}$ & & D. variabilis & [72] \\
\hline TAP & Blood coagulation & Factor Xa & & Ornithodoros moubata & [79] \\
\hline Moubatin & $\begin{array}{c}\text { Platelet activation and } \\
\text { vasoconstriction inhibitor }\end{array}$ & $\begin{array}{l}\text { Collagen-stimulated } \\
\text { aggregation activator }\end{array}$ & & O. moubata & {$[68,78]$} \\
\hline Disaggregin & Platelet aggregation & Platelet fibrinogen receptor & & O. moubata & [63] \\
\hline Enolase & Blood coagulation & Fibrin, plasminogen receptor & & O. moubata & [58] \\
\hline Savignygrin & Platelet Aggregation & Thrombin & & Ornithodoros savignyi & [67] \\
\hline Longicornin & Platelet aggregation & Collagen & & H. longicornis & [54] \\
\hline Ornithodorin & Blood coagulation & Thrombin & & O. moubata & [76] \\
\hline Salp14 & Blood coagulation & Factor Xa & & I. scapularis & [47] \\
\hline Variabilin & Platelet aggregation & Glycoprotein IIb-IIIa & & D. variabilis & [77] \\
\hline Serpin19 & Blood coagulation & $\begin{array}{c}\text { Factor Xa, factor XIa, trypsin, } \\
\text { plasmin }\end{array}$ & & Amblyomma americanum & [64] \\
\hline RmS-15 & Blood coagulation & Thrombin & & $\begin{array}{l}\text { Rhipicephalus (Boophilus) } \\
\text { microplus }\end{array}$ & [80] \\
\hline Longistatin & Blood coagulation & Fibrin & & H. longicornis & [50] \\
\hline IxscS-1E1 & Blood coagulation & Thrombin, trypsin & & I. scapularis & [61] \\
\hline IRS-2 † & Blood coagulation & $\begin{array}{l}\text { Inhibits Cathepsin } \mathrm{G} \text { and } \\
\text { chymase proteases }\end{array}$ & & I. ricinus & [55] \\
\hline Ir-CP1 & Blood coagulation & $\begin{array}{l}\text { Inhibitor of contact system } \\
\text { proteins }\end{array}$ & & I. ricinus & [57] \\
\hline Variegin & Blood coagulation & $\begin{array}{l}\text { Direct competitive inhibitor } \\
\text { of Thrombin }\end{array}$ & & Amblyomma variegatum & {$[65,66]$} \\
\hline Amblyomin-X & Blood coagulation & $\begin{array}{l}\text { Noncompetitive inhibitor of } \\
\text { coagulation factor, Factor Xa }\end{array}$ & & A. variegatum & {$[51,52]$} \\
\hline Ixolaris & Blood coagulation & $\begin{array}{l}\text { Inhibitor of contact system } \\
\text { proteins, binds to Factor Xa }\end{array}$ & & I. scapularis & {$[53,59,70]$} \\
\hline Iris + & Blood coagulation & $\begin{array}{c}\text { Thrombin, Factor } \mathrm{Xa} \text {, tissue } \\
\text { plasminogen activation } \\
\text { inhibitor }\end{array}$ & & I. ricinus & [48] \\
\hline Savignin & Blood coagulation & Thrombin & & O. savignyi & [71] \\
\hline TSGP3 & $\begin{array}{l}\text { Platelet aggreagation and } \\
\text { vasoconstriction inhibitor }\end{array}$ & $\begin{array}{c}\text { Inhibition Collagen-platelet } \\
\text { binding and interaction with } \\
\text { thromboxane A2 }\end{array}$ & & O. savignyi & [68] \\
\hline TIX-5 & Blood coagulation & Factor $\mathrm{Xa}$, factor $\mathrm{V}$ & & I. scapularis & [74] \\
\hline
\end{tabular}

\subsubsection{Complement}

The complement system is a series of protein cascades that function as part of the innate immune response, recognizing damaged tissue and microbial invaders. Three complement pathways have been characterized: The classical, lectin, and alternative pathway. Complement is always active at low levels, with regulators active to control the 
response [106]. When pattern recognition molecules, such as C1q, antibodies, and pentraxins, bind to foreign molecules, microbes, apoptotic, or damaged cells, other proteins in the complex are activated leading to the amplification of the cascade. This cascade results in lysis of the cell through the creation of pores in the cell's membrane by the membrane attack complex. Other outcomes from the activation of the complement pathways include opsonization, phagocytosis, B cell activation, $\mathrm{T}$ cell regulation, and the activation of inflammatory signaling [106-109]. The complement pathways act as a sentinel and control during tissue damage and pathogen invasion. Thus, it is not surprising that ticks have evolved several effector proteins that target components in the complement cascade, specifically C3 and C5 (Table 2), which benefit pathogen transmission.

Table 2. Described immunomodulatory components in tick saliva *.

\begin{tabular}{|c|c|c|c|c|c|c|}
\hline Component & Function/Activity & Target Effector/Protein & Cells Affected & Pathogen & Tick Species & References \\
\hline † Iris & $\begin{array}{l}\text { Th } 2 \text { response } \\
\text { modulation }\end{array}$ & $\begin{array}{l}\text { Reduction in } \mathrm{TNF} \alpha, \mathrm{INF} \gamma \\
\text { IL-8, IL-6, and IL-1 } \beta \\
\text { expression }\end{array}$ & $\begin{array}{l}\text { Macrophages, } \\
\text { T-lymphocyte }\end{array}$ & & I. ricinus & [97] \\
\hline Salp15 & $\begin{array}{l}\text { IL-2 inhibitor, T-cell } \\
\text { proliferation (I. } \\
\text { scapularis), IL-10 } \\
\text { secretion inhibitor } \\
\text { (I. ricinus) }\end{array}$ & OspC & $\begin{array}{c}\text { T cells and } \\
\text { peripheral blood } \\
\text { mononuclear cells } \\
\text { (PBMCs) }\end{array}$ & B. burgdorferi & $\begin{array}{l}\text { I. scapularis, } I . \\
\text { ricinus }\end{array}$ & $\begin{array}{c}{[86,91,94,} \\
99,100]\end{array}$ \\
\hline $\begin{array}{c}\text { IL-2 } \\
\text { Binding } \\
\text { Protein }\end{array}$ & $\mathrm{T}$ cell proliferation & IL-2 & $\begin{array}{l}\text { T cells and } \\
\text { PBMCs }\end{array}$ & & I. scapularis & {$[16]$} \\
\hline IR-LBP & $\begin{array}{l}\text { Neutrophil } \\
\text { migration }\end{array}$ & Leukotriene B4 & Neutrophils & & I. ricinus & [86] \\
\hline Irac I \& II & $\begin{array}{l}\text { Complement } \\
\text { inhibitor }\end{array}$ & C3 convertase & & & I. ricinus & [88] \\
\hline Isac & $\begin{array}{c}\text { Complement } \\
\text { inhibitor }\end{array}$ & C3 convertase & & & I. scapularis & {$[104]$} \\
\hline $\begin{array}{l}\text { Salp16 } \\
\text { Iper1 }\end{array}$ & $\begin{array}{l}\text { Neutrophil } \\
\text { migration and } \\
\text { reactive oxygen } \\
\text { species (ROS) } \\
\text { inhibitor }\end{array}$ & & Neutrophils & A. phagocytophilum & I. persuculatus & [21] \\
\hline $\begin{array}{l}\text { Salp16 } \\
\text { Iper2 }\end{array}$ & $\begin{array}{c}\text { Neutrophil } \\
\text { migration and ROS } \\
\text { inhibitor }\end{array}$ & & Neutrophils & A. phagocytophilum & I. persculutaus & [21] \\
\hline † IRS-2 & Immune inhibitor & $\begin{array}{l}\text { IL-6, IL-9, and IL-17 } \\
\text { secretion STAT-3 } \\
\text { phosphorylation }\end{array}$ & $\begin{array}{l}\text { Dendritic cells, } \\
\text { Neutrophils, and } \\
\text { Th17 cells }\end{array}$ & B. burgdorferi & I. ricinus & [23] \\
\hline $\begin{array}{l}\text { Sialostatin } \\
\text { L and L2 }\end{array}$ & Immune inhibitor & $\begin{array}{l}\text { Cathepsin L and S inhibitor, } \\
\text { inflammasome formation }\end{array}$ & & $\begin{array}{l}\text { B. burgderfori, } \\
\text { L2-TBEV and } A \text {. } \\
\text { phagocytophilum }\end{array}$ & I. scapularis & {$[38,41,42]$} \\
\hline Japanin & $\begin{array}{l}\text { Modulates DC } \\
\text { maturation }\end{array}$ & $\begin{array}{l}\text { Inhibits IL- } 1 \beta, \text { IL- } 6, \text { IL-12, } \\
\text { IFN- } \gamma \text {, and TNF } \alpha \text { secretion, } \\
\text { CD86 and CD83 expression. } \\
\text { Enhances IL-10 secretion } \\
\text { and CD274 expression }\end{array}$ & Dendritic cells & & $\begin{array}{c}R . \\
\text { appendiculatus }\end{array}$ & [24] \\
\hline IrSPI & $\mathrm{T}$ cell proliferation & $\begin{array}{c}\text { CXCL10, CCL7, CCL4, } \\
\text { CCL5, Eotaxin, IFN- } \gamma \text {, } \\
\text { IL-1 } \beta, \text { IL-18, IL-13, IL-6, } \\
\text { TNF } \alpha \text {, IL-9, and } \\
\text { Granulocyte } \\
\text { macrophage-colony } \\
\text { stimulating factor } \\
\text { (GM-CSF) inhibition and } \\
\text { IL-2 }\end{array}$ & $\mathrm{CD}^{++} \mathrm{T}$ cells & & I. ricinus & [87] \\
\hline
\end{tabular}


Table 2. Cont

\begin{tabular}{|c|c|c|c|c|c|c|}
\hline Component & Function/Activity & Target Effector/Protein & Cells Affected & Pathogen & Tick Species & References \\
\hline$+\mathrm{PGE}_{2}$ & Immune inhibitor & $\begin{array}{l}\text { Inhibition of IL-12, TNF } \alpha \text {, } \\
\text { and CD40 and } \\
\text { upregulation of IL-10 (I. } \\
\text { scapularis), increased } \\
\text { macrophage PGE }, \text { CCL5, } \\
\text { TNF } \alpha, \text { and sTNFRI } \\
\text { secretion }(D . \text { variabilis), and } \\
\text { TNF } \alpha \text { inhibition }(A . \\
\text { sculptum) }\end{array}$ & $\begin{array}{l}\text { Bovine } \\
\text { mononuclear } \\
\text { cells, DCs, and } \\
\text { macrophages }\end{array}$ & Rickettsia rickettsii & $\begin{array}{l}R . \text { (Boophilus) } \\
\text { microplus, } I \text {. } \\
\text { scapularis, } D \text {. } \\
\text { variabilis, and } \\
\text { Amblyomma } \\
\text { sculptum }\end{array}$ & $\begin{array}{l}{[72,90,95,} \\
101]\end{array}$ \\
\hline $\begin{array}{l}\text { Macrophage } \\
\text { Migration } \\
\text { Inhibitory } \\
\text { Factor } \\
\text { (MIF) } \\
\text { homolog }\end{array}$ & $\begin{array}{l}\text { Macrophage } \\
\text { migration }\end{array}$ & & Macrophages & & A. americanum & [22] \\
\hline $\begin{array}{l}\text { BIP (B-cell } \\
\text { inhibitory } \\
\text { protein) }\end{array}$ & B cell proliferation & & B cells & B. burgdorferi & I. ricinus & [91] \\
\hline $\begin{array}{c}\text { B-cell } \\
\text { inhibitory } \\
\text { factor (BIF) }\end{array}$ & B cell proliferation & & B cells & & $\begin{array}{c}\text { Hyalomma } \\
\text { asiaticum }\end{array}$ & [105] \\
\hline Amregulin & $\begin{array}{l}\text { Immune inhibitor } \\
\text { and antioxidant }\end{array}$ & $\begin{array}{l}\text { TNF } \alpha, \text { IFN- } \gamma, \text { IL-1, IL-8, } \\
\text { and Nitric Monoxide } \\
\text { (NMO) inhibitor }\end{array}$ & & & A. variegatum & [102] \\
\hline tHRF & Histamine release & $\begin{array}{l}\text { Histamine release } \\
\text { stimulation }\end{array}$ & Basophils & B. burgdorferi & & [49] \\
\hline TSGP2/3 & $\begin{array}{l}\text { Neutrophil } \\
\text { migration and } \\
\text { complement } \\
\text { inhibition }\end{array}$ & $\begin{array}{c}\text { Leukotriene B4 and C5 } \\
\text { binding }\end{array}$ & & & O. savignyi & [68] \\
\hline Salp20 & $\begin{array}{l}\text { Complement } \\
\text { inhibition }\end{array}$ & $\begin{array}{c}\text { C3 convertase (from } \\
\text { properdin displacement) }\end{array}$ & & B. burgdorferi & I. scapularis & {$[93,96,104]$} \\
\hline Iristatin & $\begin{array}{l}\text { T cell proliferation } \\
\text { and immune } \\
\text { inhibition }\end{array}$ & $\begin{array}{l}\text { IFN- } \gamma \text {, IL-2, IL-4, IL-6, and } \\
\text { IL-9 secretion, CD4 }{ }^{+} \text {T cell } \\
\text { proliferation, neutrophil } \\
\text { migration, and nitric oxide } \\
\text { production }\end{array}$ & $\begin{array}{l}\text { Neutrophils, } \\
\text { macrophages, } \mathrm{T} \\
\text { and mast cells }\end{array}$ & & I. ricinus & [96] \\
\hline DsCystatin & Immunomodulation & $\begin{array}{c}\text { Cathepsin L and B } \\
\text { inhibitor, TNF } \alpha \text {, IL-6, IL1 } \beta, \\
\text { and IFN } \gamma \text { inhibition, and } \\
\text { promotes TRAF6 } \\
\text { degradation }\end{array}$ & Macrophages & B. burgdorferi & $\begin{array}{l}\text { Dermacenter } \\
\text { silvarum }\end{array}$ & [101] \\
\hline
\end{tabular}

t: Denotes as having anti-hemostatic function as well. * adapted and updated from $[3,19,25,81]$.

Members of the B. burgdorferi s.s. and s.l. complexes are the causative agents of Lyme disease in the US and Europe. They are gram-negative spirochete bacteria, transmitted by Ixodid ticks. Borrelia spp. pathogens are some of the tick-borne pathogens that specially benefit from the dampening of the complement pathway. Borrelia spp. pathogens activate all complement pathways, even in the absence of Borrelia specific antibodies [110]. Therefore, they have acquired several mechanisms by which they can escape complement killing, including the exploitation of tick salivary components. For example, Salp20 and Isac both inhibit complement activity, enhancing B. burgdorferi transmission [96,104,105]. TSLPI (tick salivary lectin pathway inhibitor), interferes with complement activation by binding to the active sites of mannose binding lectin, a C-type lectin that detects oligosaccharides. This protein also hinders the phagocytosis of the bacteria by neutrophils and the rest of the cascade that finalizes with the membrane attack complex [111]. Furthermore, B. burgdorferi increases transcription of this protein in the salivary glands of nymphs [111], possibly to increase its survival. A homolog to this protein was identified in I. ricinus, and it protects both B. burgdorferi s.s. and 
B. garinii from complement killing during in vitro tests [112]. Other tick-borne pathogens may also take advantage of these effector to survive the mammalian complement cascade.

\subsubsection{Immune Cells}

Mechanical abrasion of the skin leads to the activation of skin immune cells that prevent the entry and establishment of pathogenic invaders into the body [113]. The immune response is mediated by specialized and non-specialized cells that have evolved to recognize non-self-antigens. Non-specialized cells, such as endothelial cells, keratinocytes, fibroblasts, and platelets communicate with specialized innate immune cells, like macrophages, DCs, neutrophils, Langerhans cells, mast cells, basophils, $\gamma \delta \mathrm{T}$ cells, and innate lymphoid cells (ILCs) $[113,114]$. These cells are largely responsible for the great majority of the immune response, from phagocytizing microbes and damaged cells as well as producing the effectors necessary for a coordinated immune response. For example, DCs with bound antigens migrate from the skin to the lymph nodes to present them to B and T cells, which in turn undergo maturation and clonal replication. In mice, and possibly humans, DCs and macrophages can interact with $\mathrm{T}$ cells in the skin during inflammation, providing a site where antigen presentation can occur. This site is termed inducible skin-associated lymphoid tissue (iSALT) and is key in the generation of adaptive immunity [114]. Phagocytes at the bite site will begin to engulf damaged tissue and invaders they may encounter in the area. Granular cells release a cocktail of compounds into the extracellular space, prepping the somatic cells for the inflammatory response, and activating other immune cells $[7,115,116]$. This complex of immune reactions and cells profoundly influences tick feeding efficiency and the outcome of pathogen transmission.

The tick encounters these defense systems during feeding, and some animal species may acquire resistance to tick feeding after infestation by generating systemic immunity [117]. This immunity has been reported in animals such as cattle, guinea pigs, and rabbits. [117-119]. This immunity has also been shown to have some effect between tick species on a single host [120]. Several immune cells, particularly basophils and resident memory T cells, have been linked with the development of this resistance. Acquired tick immunity (AIT) can disrupt the ability of ticks to complete a blood meal, reproduce, and even transmit pathogens. The effects of cellular immunity on tick physiology has resulted in evolutionary pressures for ticks to develop several molecules that can counter immune cell activation, migration, and proliferation (Table 2). One example of such immunomodulatory proteins is the serpin Iris (Figure 1). Iris is an immunosuppressant that affects $\mathrm{T}$ cell proliferation and cytokine secretion by macrophages, promoting a Th2 response with the generation of high antibody titers that by themselves are ineffective in controlling infections with tick-borne pathogens [97,121,122].

Tick-borne pathogens take advantage of these molecules by increasing their expression and may use them as a protective coat. B. burgdorferi selectively enhances Salp15 expression in SGs and directly binds Salp15 through OspC, a spirochete surface protein [99]. Salp15 and its orthologs have also been shown to inhibit the activation of CD4+ T-lymphocytes and keratinocytes [123-125] (Figure 1). BIP (B-cell inhibitory protein), identified from I. ricinus SGs, inhibits OspC-induced B lymphocyte proliferation [91]. Therefore, facilitating B. burgdorferi infection. Similarly, A. phagocytophilum, a gram-negative obligate intracellular tick-borne bacterium that colonizes polymorphonuclear neutrophils, increases the expression of Salp16, where it is required for the initial infection of the salivary gland [125]. This protein is involved in the inhibition of neutrophils and decreased reactive oxygen species (ROS) production [21]. However, whether A. phagocytophilum uses this protein for its transmission has not been defined.

\subsubsection{Cytokine and Chemokine Secretion}

Cytokines are a collection of effector molecules, modulating innate and adaptive immune responses through a network of complex and at times, contradictory interactions. These proteins interact with immune cells and neurons to coordinate immune responses, including 
the inflammation of tissues, aggregation of immune cells and somatic cells, proliferation of immune cells, cell recruitment, T cell differentiation, maturation of B-cells, and itch [126-128]. Itch sensations if left unchecked, would lead to injury awareness and to the host scratching or grooming, leading to tick dislodgement. Ticks dampen itch sensations through secreted salivary components such as lipocalins that bind histamine and degrade bradykinin, mediators of pain and itch $[20,25]$. Chemokines are $8-12 \mathrm{kD}$ molecules that induce a chemotaxis of various immune cell types, including neutrophils, monocytes, lymphocytes, eosinophils, $\mathrm{T}$ and $\mathrm{B}$ cells fibroblasts, and keratinocytes [126,127]. Keratinocytes and other cells in the skin secrete cytokines upon infection or damage [129]. Platelets also express several chemokine receptors that activate their migration, aggregation, and granule release [130]. Thus, cytokines and chemokines play a crucial role in the response against ticks and tick-borne pathogens. However, ticks secrete several effectors that affect the expression and regulation of cytokines and chemokines at the bite site (Table 2). IRS-2, for example, diminishes the secretion of IL-6 and IL-17 and the development of Th17 helper T cells [23], which are an important subset of T cells found in the skin. IL-17 has been associated with the production of antibodies against $B$. burgdorferi during early Lyme disease [128]. Therefore, the dampened Th17 T cell development and IL-17 secretion likely benefits B. burgdorferi early infection and establishment in the skin.

\subsubsection{Histamine Secretion}

Immune cells secrete other immune effectors, including histamine. Histamine influences the polarization of immune responses and the maturation of immune cells [131]. Furthermore, histamine is an important effector secreted by basophils and mast cells in response to tick bites and has been associated with anti-tick immunity [117]. However, although ticks secrete several histamine binding proteins that may block the effect of some of the histamine at the bite site, it appears certain levels of it benefit tick feeding and pathogen transmission. tHRF is a protein that has been found in I. scapularis and $D$. andersoni saliva $[49,69]$. This protein binds to basophils, inducing histamine release and promoting vasodilation. Interestingly, this protein is upregulated by B. burgdorferi infection and is required for the efficient transmission of this pathogen. While seemingly detrimental to the tick, and potentially the pathogen, by increasing the blood flow into the bite site, pathogens may facilitate their own dissemination in the host [49].

\section{Global Manipulation of Tick Sialome by Pathogens}

The sialome of the tick consists of mRNAs and proteins expressed in the salivary glands [132]. Global studies on tick salivary gland gene expression have identified over 287,000 transcripts from which over 45,000 putative secretory proteins have been identified [133]. However, only a small proportion $(\sim 5 \%)$ of salivary gland proteins have had their predicted functions verified [8]. In order to be transmitted to the vertebrate host, tick-borne pathogens must first invade the tick salivary glands where they manipulate the sialome. Several studies have demonstrated the ability of tick-borne pathogens to change the gene expression in tick salivary glands. We will focus on three pathogens: A. phagocytophilum, B. burgdorferi complex, and TBEV, and the processes that they manipulate to facilitate their transmission.

A proteomic screening revealed that $A$. phagocytophilum increases the expression of anticlotting proteins, immune inhibitor proteins, and prolyl 4-hydroxylase subunits in I. scapularis salivary glands [134] (Figure 2A). The anticlotting factors include Salp9 [47] and Salp11 [135] and thrombin inhibitors. Another anticlotting factor, Metis-1, is upregulated during Anaplasma infection. Metis-1 is a salivary gland specific to metalloprotease thought to stimulate fibrinolysis [56]. Immune inhibitors, Sialostatin L and Sialostatin L2, also have increased protein levels [134]. Multiple subunits of the proline 4-hydroylase enzyme are upregulated in salivary glands with A. phagocytophilum infection. While this enzyme is canonically known to modify and stabilize collagen [8], it has an uncharacterized function in tick saliva and tick salivary glands [133]. However, there is a high 
abundance of tick cement proteins with proline hydroxylation motifs [133], suggesting that $A$. phagocytophilum may be enriching for a subtype of cement proteins. Additionally, proyly hydroxylase-mediated upregulation of a putative ACE I in salivary glands may function to degrade bradykinin, which is involved in pain sensation and edema $[20,134]$. The overall effect of $A$. phagocytophilum manipulation of the tick sialome seems to enhance tick feeding success by increasing anticlotting activity as well as reducing pain sensation and edema. Additionally, A. phagocytophilum may selectively enhance a subpopulation of cement proteins with uncharacterized functional significance (Figure 2A).

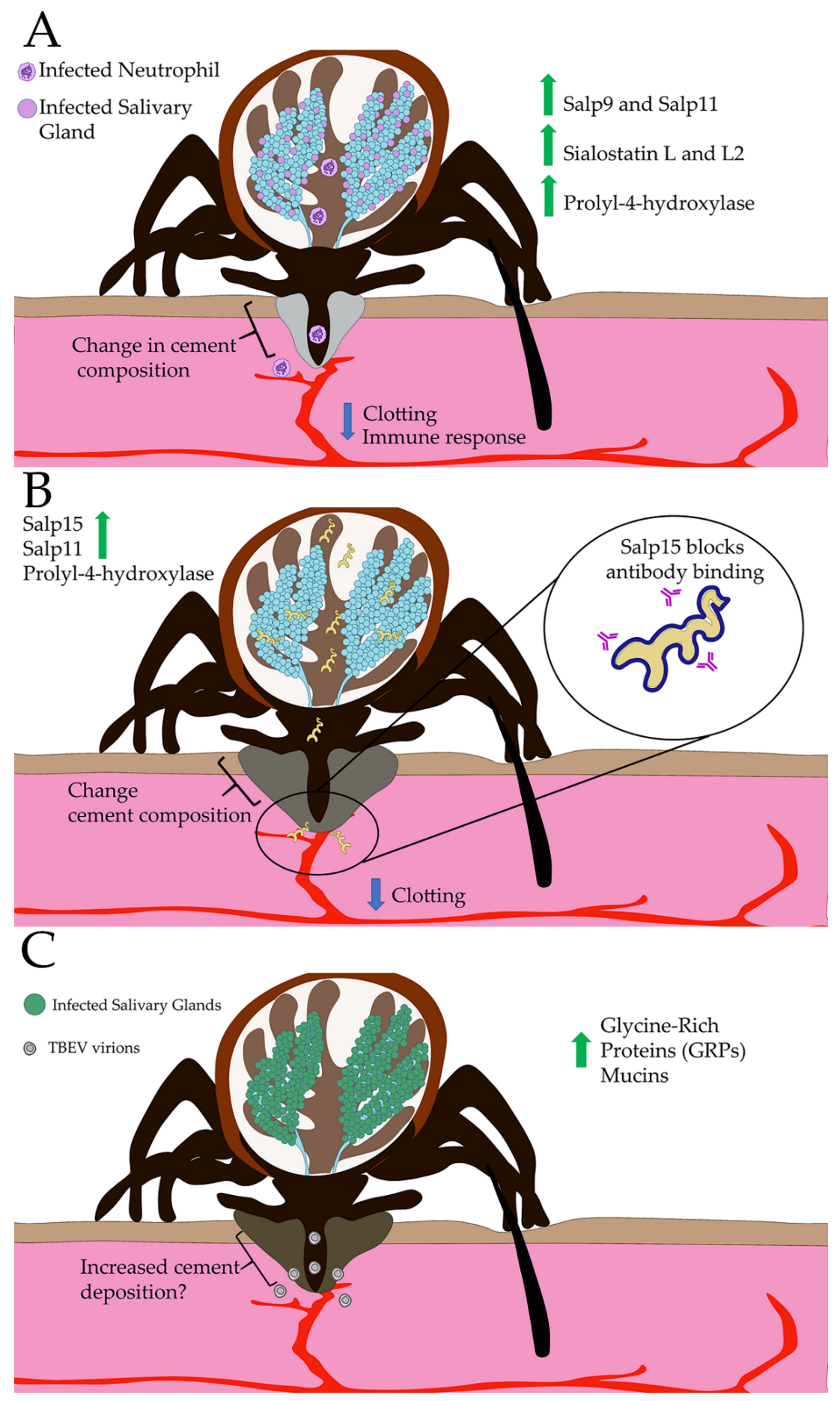

Figure 2. Tick-borne pathogens manipulate the expression of tick salivary effectors to enhance their transmission. (A) A. phagocytophiluminfected neutrophils are taken up by the tick during its bloodmeal. Once in the tick, A. phagocytophilum infects salivary glands as early as 24 to $48 \mathrm{~h}$. In the salivary glands, 
A. phagocytophilum leads to increased protein levels of the anticoagulants Salp9 and Salp11, the immune inhibitors Sialostatin L and L2, and a prolyl 4-hydroxylase. Sialostatin L and L2 are cystatins that bind and inhibit cathepsins L and S, leading to decreased and altered immune responses at the bite site. Prolyl 4-hydroxlases are enzymes that hydroxylate prolines and are necessary for collagen stability. Furthermore, the presence of proline hydroxylation motifs in several cement proteins suggests that $A$. phagocytophilum may influence the composition of the cement cone. (B) Borrelia pathogens selectively increases Salp15 expression in salivary glands. Salp15 directly binds OspC in the surface of Borrelia burgdorferi. The Salp15 coating blocks OspC specific antibodies from binding the bacteria, inhibiting both direct antibody mediated killing and activation of complement pathways. Salp11 and prolyl 4-hydroxylase proteins levels are increased during Borrelia infection, delaying clot formation and potentially affecting collagen stability. Similarly to A. phagocytophilum, the effect of $B$. burgdorferi infection on prolyl 4-hydroxylase expression may indicate that bacterial infection leads to modifications in the composition of the cement cone. (C) TBEV infection alters the expression of genes encoding several cement proteins, mucins, and glycine-rich proteins. The increased expression of glycine-rich proteins may represent an overall increase in tick cement proteins or a compositional shift of cement proteins being deposited to form the cement cone. This compositional change may be necessary for TBEV transmission as vaccination with a glycine rich protein resulting in protection against virus infection.

B. burgdorferi, like A. phagocytophilum, increases the expression of several common anticlotting factors and cement proteins [136]. Anticlotting factors Salp11 and Metis-1 levels are increased during Borrelia infection compared to uninfected controls. Other proteins include a prolyl hydroxylase, also affected during $A$. phagocytophilum infection, suggesting that the exploitation of anticoagulants, and potentially collagen integrity (Figure 2B), benefits infection. Manipulation of the expression of salivary proteins appears to be a conserved mechanism used by Borrelia spp. bacteria. Borrelia afzelii, the main causative agent of Lyme disease in Europe, also alters the gene expression in the salivary glands of I. ricinus [137]. Using two different sequencing approaches to determine gene expression levels, Trentelman et al. [137] determined that B. afzelii had the biggest effect on salivary protein gene expression at $24 \mathrm{~h}$ of feeding, affecting 465 genes. These include genes encoding statins, immunity relate genes, signal transduction, ixodegrin family, Salp15 family, protein export, metalloproteases, lipocalins, and serine proteases. Lipocalins are a family of conserved proteins that bind to diverse targets, including histamine, Leukotriene B4 (LTB4), and others. B. azfelii infection increases the expression of a lipocalin, JAA67401, a putative serotonin binding protein [138]. Serotonin and the metabolites generated in the serotonin pathway are important in coordination between the neuroendocrine and immune systems. Serotonin, melatonin, and other neurometabolites are produced by immune cells and are substrates for enzymes that synthesize immunomodulators and anti-inflammatory molecules [139]. Whether other Borrelia species also manipulate these genes has not been tested. However, both B. afzelii and B. burgdorferi enhance the expression of Salp15 [123], indicating potentially conserved mechanisms to evade antibody recognition (Figure 2B).

RNA-seq analysis of the salivary glands of TBEV-infected I. ricinus females attached for 1 or $3 \mathrm{~h}$ shows that TBEV infection increases the expression of anticlotting/immunomodulatory genes (lipocalins, metalloproteases, protease inhibitors, and lectins), and genes encoding cement proteins (four mucin genes and 11 genes for glycine rich proteins) [140]. In this study, the authors speculated that since most of the mucins and glycine rich proteins were upregulated within 1 hour of attachment, a potential shift in the composition of the cement cone that may occur compared to uninfected ticks. The importance of these proteins is highlighted by the protective effect that vaccination using a glycine rich protein, 64TRP, has against TBEV transmission to mice [141] (Figure 2C).

Interestingly, A. phagocytophilum, B. burgdorferi, and TBEV, all manipulate gene expression in tick salivary glands, in particular those coding for anticlotting factors, immune inhibitors, and proteins involved in cement protein production. A. phagocytophilum and 
B. burgdorferi both upregulate levels of Salp11, Metis-1, and prolyl 4-hydroxylase. All three also increase the expression of genes encoding immunomodulatory proteins. While there are some data showing that cement protein expression changes during infection with all three pathogens, only the increase in glycine rich proteins in TBEV-infected salivary glands has some documented benefit for pathogen transmission. Together, these studies suggest that these pathogens may target similar effectors and pathways to enhance tick feeding success and vertebrate host immune evasion to facilitate their transmission.

\section{Conclusions}

To support the uptake of large volumes of blood over a long duration of time, ticks have evolved a large repertoire of salivary molecules to counteract host defense mechanisms. Tick saliva contains components that interfere with normal hemostasis and immunological mechanisms at the bite site. The immunomodulatory components in tick saliva create a privileged environment that can enhance the survival and transmission of tick-borne pathogens. In this context, it is not surprising that tick-borne pathogens direct changes in tick salivary glands and saliva to further their survival and transmission, by modifying gene expression and directly binding to salivary products. This review focused mainly on proteinaceous effectors. Nevertheless, tick-borne pathogens may enhance their transmission by exploiting other molecules. A recent study has shown that Powassan virus, a TBEV complex member, is able to alter the expression of miRNAs in the salivary glands of I. scapularis ticks [142], several of which represent novel miRNAs not previously reported, while others match previously identified sequences. These findings are corroborated by the in vitro transfection of monkey kidney (Vero) epithelial cells with inhibitors of some of these miRNAs before infection with the Powassan virus which resulted in either higher or lower viral loads. These results suggested that the secretion of these miRNAs in tick saliva may serve to limit infection at certain time points, while aiding at others. miRNAs have been detected in the saliva of other tick species $[143,144]$. Thus, other pathogens may also target miRNAs expression to facilitate their transmission.

Another yet unexplored mechanism by which tick-borne pathogens may hijack the secretion of salivary effectors is the manipulation of extracellular vesicles. Extracellular vesicles are small lipid blebs that secrete for cell-to-cell communication. Extracellular vesicles have been detected in the saliva of I. scapularis, Amblyomma maculatum, and H. longicornis [145-147]. Vesicles from H. longicornis contain known protein effectors, like lipocalins, cement-like proteins, and serpins as well as novel miRNAs suspected to influence host immune responses $[145,146]$. Furthermore, in vitro experiments indicate that vesicles from I. scapularis and A. maculatum diminish chemokine and cytokine secretion and delay wound healing responses [147]. Several studies have shown their immunomodulating effects and influence on infection by several vector-borne pathogens [148], including the transmission of Langat virus (LGTV) from tick cells to mammalian cells [149]. Interestingly, LGTV was not only able to change the proteomic and genomic cargo of the vesicles by adding its own material, but also increased the number of extracellular vesicles secreted. It is possible that other tick-borne pathogens similarly influence the cargo and secretion of these vesicles to facilitate their transmission.

A major goal of studying the tick-host-pathogen interface is the discovery of the genetic components and molecular pathways that contribute towards the transmission of tick-borne pathogens. While so far only a few factors and mechanisms have been identified, it is evident that tick-borne pathogens manipulate salivary gland components to enhance tick feeding success and their transmission to the host. Distinguishing and characterizing these immunomodulatory molecules could serve to identify potential targets for the development of future tick control measures and vaccine targets that could positively block tick-borne pathogen transmission.

Author Contributions: Conceptualization, A.S.O.C.; preparation of figures, M.P. and A.S.O.C.; writing manuscript, M.P., J.U., and A.S.O.C.; Edited manuscript, M.P. and A.S.O.C. All authors have read and agreed to the published version of the manuscript. 
Funding: This work was funded with the startup funds provided by Texas A\&M AgriLife Research to A.S.O.C.

Institutional Review Board Statement: Not applicable.

Informed Consent Statement: Not applicable.

Data Availability Statement: No new data were created or analyzed in this study. Data sharing is not applicable to this article.

Acknowledgments: We thank Ulrike Munderloh at the University of Minnesota and Cross Chambers for his assistance in proofreading the drafts.

Conflicts of Interest: The authors declare no conflict of interest.

\section{References}

1. Jongejan, F.; Uilenberg, G. The global importance of ticks. Parasitology 2004, 129, S3-S14. [CrossRef] [PubMed]

2. Barker, S.C.; Murrell, A. Systematics and evolution of ticks with a list of valid genus and species names. Parasitology 2004, 129, S15-S36. [CrossRef] [PubMed]

3. Wikel, S.K. Tick-Host Interactions. In Biology of Ticks, 2nd ed.; Sonenshine, D., Roe, R.M., Eds.; Oxford University Press: New York, NY, USA, 2014; Volume 2, p. 88.

4. Alarcon-Chaidez, F. Salivary glands. In Biology of Ticks, 2nd ed.; Sonenshine, D., Roe, R.M., Eds.; Oxford University Press: New York, NY, USA, 2014; Volume 1.

5. Anderson, J.F.; Magnarelli, L.A. Biology of ticks. Infect. Dis. Clin. N. Am. 2008, 22, 195-215. [CrossRef]

6. Richter, D.; Matuschka, F.-R.; Spielman, A.; Mahadevan, L. How Ticks Get Under your Skin: Insertion Mechanics of the Feeding Apparatus of Ixodes ricinus Ticks. Proc. Biol. Sci. 2013, 280, 20131758. [CrossRef]

7. Brossard, M.; Wikel, S.K. Tick Immunobiology. Parasitology 2004, 129, S161-S176. [CrossRef] [PubMed]

8. Francischetti, I.M.B.; Sa-Nunes, A.; Mans, B.J.; Santos, I.M.; Ribeiro, J.M.C. The Role of Saliva in Tick Feeding. Front. Biosci. 2009, 14, 2051-2088. [CrossRef]

9. Lebre, M.C.; Am van, d.A.; van, B.L.; van, C.T.M.; Schuitemaker, J.H.; Kapsenberg, M.L.; de, J.E.C. Human Keratinocytes Express Functional Toll-like Receptor 3, 4, 5, and 9. J. Investig. Dermatol. 2007, 127. [CrossRef]

10. Nestle, F.O.; Di Meglio, P.; Qin, J.-Z.; Nickoloff, B.J. Skin Immune Sentinels in Health and Disease. Nat. Rev. Immunol. 2009, 9, 679-691. [CrossRef]

11. Klicznik, M.M.; Szenes-Nagy, A.B.; Campbell, D.J.; Gratz, I.K. Taking the Lead-How Keratinocytes Orchestrate Skin T cell Immunity. Immunol. Lett. 2018, 200, 43-51. [CrossRef]

12. Maouia, A.; Rebetz, J.; Kapur, R.; Semple, J.W. The Immune Nature of Platelets Revisited. Transfus. Med. Rev. 2020, 34, 209-220. [CrossRef] [PubMed]

13. Zuchtriegel, G.; Uhl, B.; Puhr-Westerheide, D.; Pörnbacher, M.; Lauber, K.; Krombach, F.; Reichel, C.A. Platelets Guide Leukocytes to Their Sites of Extravasation. PLoS Biol. 2016, 14, e1002459. [CrossRef] [PubMed]

14. Kissenpfennig, A.; Henri, S.; Dubois, B.; Laplace-Builhé, C.; Perrin, P.; Romani, N.; Tripp, C.H.; Douillard, P.; Leserman, L.; Kaiserlian, D.; et al. Dynamics and Function of Langerhans Cells in vivo: Dermal Dendritic cells Colonize Lymph Node Areas Distinct from Slower Migrating Langerhans cells. Immunity 2005, 22. [CrossRef] [PubMed]

15. Nithiuthai, S.; Allen, J.R. Langerhans cells Present Tick Antigens to Lymph Node cells from Tick-sensitized Guinea-pigs. Immunology 1985, 55, 157.

16. Gillespie, R.D.; Dolan, M.C.; Piesman, J.; Titus, R.G. Identification of an IL-2 Binding Protein in the Saliva of the Lyme Disease Vector Tick, Ixodes scapularis. J. Immunol. 2001, 166, 4319-4326. [CrossRef]

17. Hajnická, V.; Vančová-Štibrániová, I.; Slovák, M.; Kocáková, P.; Nuttall, P.A. Ixodid Tick Salivary Gland Products Target Host Wound Healing Growth Factors. Int. J. Parasitol. 2011, 41, 213-223. [CrossRef] [PubMed]

18. Fontaine, A.; Diouf, I.; Bakkali, N.; Missé, D.; Pagès, F.; Fusai, T.; Rogier, C.; Almeras, L. Implication of Haematophagous Arthropod Salivary Proteins in Host-vector Interactions. Parasit. Vectors 2011, 4. [CrossRef] [PubMed]

19. Nuttall, P.A. Tick Saliva and its Role in Pathogen Transmission. Wien. Klin. Wochenschr. 2019. [CrossRef] [PubMed]

20. Ribeiro, J.M.C.; Mather, T.N. Ixodes scapularis:Salivary Kininase Activity Is a Metallo Dipeptidyl Carboxypeptidase. Exp. Parasitol. 1998, 89, 213-221. [CrossRef]

21. Hidano, A.; Konnai, S.; Yamada, S.; Githaka, N.; Isezaki, M.; Higuchi, H.; Nagahata, H.; Ito, T.; Takano, A.; Ando, S.; et al. Suppressive Effects of Neutrophil by Salp16-like Salivary Gland Proteins from Ixodes persulcatus Schulze tick. Insect Mol. Biol. 2014, 23, 466-474. [CrossRef]

22. Jaworski, D.C.; Jasinskas, A.; Metz, C.N.; Bucala, R.; Barbour, A.G. Identification and Characterization of a Homologue of the Pro-inflammatory Cytokine Macrophage Migration Inhibitory Factor in the Tick, Amblyomma americanum. Insect Mol. Biol. 2001, 10, 323-331. [CrossRef]

23. Páleníková, J.; Lieskovská, J.; Langhansová, H.; Kotsyfakis, M.; Chmelař, J.; Kopecký, J. Ixodes ricinus Salivary Serpin IRS-2 Affects Th17 Differentiation via Inhibition of the Interleukin-6/STAT-3 Signaling Pathway. Infect. Immun. 2015, 83, 1949-1956. [CrossRef] 
24. Preston, S.G.; Majtán, J.; Kouremenou, C.; Rysnik, O.; Burger, L.F.; Cabezas Cruz, A.; Chiong Guzman, M.; Nunn, M.A.; Paesen, G.C.; Nuttall, P.A.; et al. Novel Immunomodulators from Hard Ticks Selectively Reprogramme Human Dendritic Cell Responses. PLoS Pathog. 2013, 9, e1003450. [CrossRef]

25. Šimo, L.; Kazimirova, M.; Richardson, J.; Bonnet, S.I. The Essential Role of Tick Salivary Glands and Saliva in Tick Feeding and Pathogen Transmission. Front. Cell. Infect. Microbiol. 2017, 7. [CrossRef] [PubMed]

26. Becchimanzi, A.; Tate, R.; Campbell, E.M.; Gigliotti, S.; Bowman, A.S.; Pennacchio, F. A Salivary Chitinase of Varroa destructor Influences Host Immunity and Mite's Survival. PLoS Pathog. 2020, 16, e1009075. [CrossRef]

27. Richards, E.H.; Jones, B.; Bowman, A. Salivary Secretions from the Honeybee Mite, Varroa destructor: Effects on Insect Haemocytes and Preliminary Biochemical Characterization. Parasitology 2011, 138, 602-608. [CrossRef]

28. Ramsey, J.S.; Chavez, J.D.; Johnson, R.; Hosseinzadeh, S.; Mahoney, J.E.; Mohr, J.P.; Robison, F.; Zhong, X.; Hall, D.G.; MacCoss, M.; et al. Protein Interaction Networks at the Host-microbe Interface in Diaphorina citri, the Insect Vector of the Citrus Greening Pathogen. R. Soc. Open Sci. 2017, 4, 160545. [CrossRef] [PubMed]

29. Orlovskis, Z.; Canale, M.C.; Thole, V.; Pecher, P.; Lopes, J.R.; Hogenhout, S.A. Insect-borne Plant Pathogenic Bacteria: Getting a Ride Goes Beyond Physical Contact. Curr. Opin. Insect Sci. 2015, 9, 16-23. [CrossRef]

30. Arena, G.D.; Ramos-Gonzalez, P.L.; Rogerio, L.A.; Ribeiro-Alves, M.; Casteel, C.L.; Freitas-Astua, J.; Machado, M.A. Making a Better Home: Modulation of Plant Defensive Response by Brevipalpus Mites. Front. Plant Sci. 2018, 9, 1147. [CrossRef] [PubMed]

31. Hogenhout, S.A.; Bos, J.I.B. Effector Proteins that Modulate Plant-insect Interactions. Curr. Opin. Plant Biol. 2011, 14, 422-428 [CrossRef]

32. Eigenbrode, S.D.; Bosque-Pérez, N.A.; Davis, T.S. Insect-Borne Plant Pathogens and Their Vectors: Ecology, Evolution, and Complex Interactions. Annu. Rev. Entomol. 2018, 63, 169-191. [CrossRef]

33. Su, Y.L.; Li, J.M.; Li, M.; Luan, J.B.; Ye, X.D.; Wang, X.W.; Liu, S.S. Transcriptomic Analysis of the Salivary Glands of an Invasive Whitefly. PLoS ONE 2012, 7, e39303. [CrossRef] [PubMed]

34. Reppert, E.; Galindo, R.C.; Ayllón, N.; Breshears, M.A.; Kocan, K.M.; Blouin, E.F.; de la Fuente, J. Studies of Anaplasma phagocytophilum in Sheep Experimentally Infected with the Human NY-18 Isolate: Characterization of Tick Feeding Sites. Ticks Tick Borne Dis. 2014, 5, 744-752. [CrossRef] [PubMed]

35. Granquist, E.G.; Aleksandersen, M.; Bergström, K.; Dumler, S.J.; Torsteinbø, W.O.; Stuen, S. A Morphological and Molecular Study of Anaplasma phagocytophilum Transmission Events at the Time of Ixodes ricinus Tick Bite. Acta Vet. Scand. 2010, 52, 43. [CrossRef] [PubMed]

36. Shih, C.M.; Chao, L.L.; Yu, C.P. Chemotactic Migration of the Lyme Disease Spirochete (Borrelia burgdorferi) to Salivary Gland Extracts of Vector Ticks. Am. J. Trop. Med. Hyg. 2002, 66, 616-621. [CrossRef]

37. Kotsyfakis, M.; Horka, H.; Salat, J.; Andersen, J.F. The crystal structures of two salivary cystatins from the tick Ixodes scapularis and the effect of these inhibitors on the establishment of Borrelia burgdorferi infection in a murine model. Mol Microbiol 2010, 77, 456-470. [CrossRef]

38. Kotsyfakis, M.; Sá-Nunes, A.; Francischetti, I.M.B.; Mather, T.N.; Andersen, J.F.; Ribeiro, J.M.C. Antiinflammatory and Immunosuppressive Activity of Sialostatin L, a Salivary Cystatin from the Tick Ixodes scapularis. J. Biol. Chem. 2006, 281, 26298-26307. [CrossRef] [PubMed]

39. Hsing, L.C.; Rudensky, A.Y. The Lysosomal Cysteine Proteases in MHC class II Antigen Presentation. Immunol. Rev. 2005, 207, 229-241. [CrossRef]

40. Klein, M.; Brühl, T.J.; Staudt, V.; Reuter, S.; Grebe, N.; Gerlitzki, B.; Hoffmann, M.; Bohn, T.; Ulges, A.; Stergiou, N.; et al. Tick Salivary Sialostatin L Represses the Initiation of Immune Responses by Targeting IRF4-Dependent Transcription in Murine Mast Cells. J. Immunol. 2015, 195, 621-631. [CrossRef] [PubMed]

41. Lieskovská, J.; Páleníková, J.; Langhansová, H.; Chagas, A.C.; Calvo, E.; Kotsyfakis, M.; Kopecký, J. Tick Sialostatins L and L2 Differentially Influence Dendritic Cell Responses to Borrelia Spirochetes. Parasit. Vectors 2015, 8. [CrossRef] [PubMed]

42. Lieskovská, J.; Páleníková, J.; Širmarová, J.; Elsterová, J.; Kotsyfakis, M.; Campos Chagas, A.; Calvo, E.; Růžek, D.; Kopecký, J. Tick Salivary Cystatin Sialostatin L2 Suppresses IFN Responses in Mouse Dendritic Cells. Parasite Immunol. 2015, 37, 70-78. [CrossRef]

43. Sá-Nunes, A.; Bafica, A.; Antonelli, L.R.; Choi, E.Y.; Francischetti, I.M.; Andersen, J.F.; Shi, G.P.; Chavakis, T.; Ribeiro, J.M.; Kotsyfakis, M. The Immunomodulatory Action of Sialostatin L on Dendritic Cells Reveals its Potential to Interfere with Autoimmunity. J. Immunol. 2009, 182, 7422-7429. [CrossRef] [PubMed]

44. Chen, G.; Wang, X.; Severo, M.S.; Sakhon, O.S.; Sohail, M.; Brown, L.J.; Sircar, M.; Snyder, G.A.; Sundberg, E.J.; Ulland, T.K.; et al. The Tick Salivary Protein Sialostatin L2 Inhibits Caspase-1-Mediated Inflammation during Anaplasma phagocytophilum Infection. Infect. Immun. 2014, 82, 2553-2564. [CrossRef] [PubMed]

45. Hoffman, R.; Benz, E.J.; Silberstein, L.E.; Heslop, H.; Weitz, J.; Anastasi, J. Overview of Hemostasis and Thrombosis. In Hematology: Basic Principles and Practice, 6th ed.; Elsevier Saunders: Philadelphia, PA, USA, 2012; pp. 1774-1783.

46. Rodrigues, M.; Kosaric, N.; Bonham, C.A.; Gurtner, G.C. Wound Healing: A Cellular Perspective. Physiol. Rev. 2019, 99, 665-706. [CrossRef]

47. Narasimhan, S.; Koski, R.A.; Beaulieu, B.; Anderson, J.F.; Ramamoorthi, N.; Kantor, F.; Cappello, M.; Fikrig, E. A Novel Family of Anticoagulants from the Saliva of Ixodes scapularis. Insect Mol. Biol. 2002, 11. [CrossRef] 
48. Prevot, P.-P.; Adam, B.; Boudjeltia, K.Z.; Brossard, M.; Lins, L.; Cauchie, P.; Brasseur, R.; Vanhaeverbeek, M.; Vanhamme, L.; Godfroid, E. Anti-hemostatic Effects of a Serpin from the Saliva of the Tick Ixodes ricinus. J. Biol. Chem. 2006, 281, 26361-26369. [CrossRef]

49. Dai, J.; Narasimhan, S.; Zhang, L.; Liu, L.; Wang, P.; Fikrig, E. Tick Histamine Release Factor Is Critical for Ixodes scapularis Engorgement and Transmission of the Lyme Disease Agent. PLoS Pathogen. 2010, 6, e1001205. [CrossRef]

50. Anisuzzaman; Islam, M.K.; Alim, M.A.; Miyoshi, T.; Hatta, T.; Yamaji, K.; Matsumoto, Y.; Fujisaki, K.; Tsuji, N. Longistatin, a Plasminogen Activator, Is Key to the Availability of Blood-Meals for Ixodid Ticks. PLoS Pathogen. 2011, 7, e1001312. [CrossRef]

51. Batista, I.F.C.; Ramos, O.H.P.; Ventura, J.S.; Junqueira-de-Azevedo, I.L.M.; Ho, P.L.; Chudzinski-Tavassi, A.M. A New Factor Xa Inhibitor from Amblyomma cajennense with a Unique Domain Composition. Arch. Biochem. Biophys. 2010, 493, 151-156. [CrossRef] [PubMed]

52. Branco, V.G.; Iqbal, A.; Alvarez-Flores, M.P.; Sciani, J.M.; Andrade, S.A.; Iwai, L.K.; Serrano, S.M.T.; Chudzinski-Tavassi, A.M. Amblyomin-X having a Kunitz-type Homologous Domain, is a Noncompetitive Inhibitor of FXa and Induces Anticoagulation in vitro and in vivo. Biochim. Biophys. Acta Proteins Proteom. 2016, 1864, 1428-1435. [CrossRef]

53. Carneiro-Lobo, T.C.; Konig, S.; Machado, D.E.; Nasciutti, L.E.; Forni, M.F.; Francischetti, I.M.B.; Sogayar, M.C.; Monteiro, R.Q. Ixolaris, a Tissue Factor Inhibitor, Blocks Primary Tumor Growth and Angiogenesis in a Glioblastoma Model. J. Thromb. Haemost. 2009, 7, 1855-1864. [CrossRef] [PubMed]

54. Cheng, Y.; Wu, H.; Li, D. An Inhibitor Selective for Collagen-stimulated Platelet Aggregation from the Salivary glands of Hard tick Haemaphysalis longicornis and its Mechanism of Action. Sci. China Life Sci. 1999, 42, 457-464. [CrossRef] [PubMed]

55. Chmelar, J.; Oliveira, C.J.; Rezacova, P.; Francischetti, I.M.B.; Kovarova, Z.; Pejler, G.; Kopacek, P.; Ribeiro, J.M.C.; Mares, M.; Kopecky, J.; et al. A tick salivary protein targets cathepsin $\mathrm{G}$ and chymase and inhibits host inflammation and platelet aggregation. Blood 2011, 117, 736-744. [CrossRef] [PubMed]

56. Decrem, Y.; Beaufays, J.; Blasioli, V.; Lahaye, K.; Brossard, M.; Vanhamme, L.; Godfroid, E. A Family of Putative Metalloproteases in the Salivary Glands of the Tick Ixodes ricinus. FEBS J. 2008, 275, 1485-1499. [CrossRef] [PubMed]

57. Decrem, Y.; Rath, G.; Blasioli, V.; Cauchie, P.; Robert, S.; Beaufays, J.; Frère, J.-M.; Feron, O.; Dogné, J.-M.; Dessy, C.; et al. Ir-CPI, a Coagulation Contact Phase Inhibitor from the Tick Ixodes ricinus, Inhibits Thrombus Formation Without Impairing Hemostasis. J. Exp. Med. 2009, 206, 2381-2395. [CrossRef]

58. Díaz-Martín, V.; Manzano-Román, R.; Oleaga, A.; Encinas-Grandes, A.; Pérez-Sánchez, R. Cloning and Characterization of a Plasminogen-binding Enolase from the Saliva of the Argasid tick Ornithodoros moubata. Vet. Parasitol. 2013, 191, 301-314. [CrossRef]

59. Francischetti, I.M.B.; Valenzuela, J.G.; Andersen, J.F.; Mather, T.N.; Ribeiro, J.M.C. Ixolaris, a Novel Recombinant Tissue Factor Pathway Inhibitor (TFPI) from the Salivary Gland of the Tick, Ixodes scapularis: Identification of Factor X and Factor Xa as Scaffolds for the Inhibition of Factor VIIa/tissue Factor Complex. Blood 2002, 99, 3602-3612. [CrossRef] [PubMed]

60. Fukumoto, S.; Sakaguchi, T.; You, M.; Xuan, X.; Fujisaki, K. Tick Troponin I-like Molecule is a Potent Inhibitor for Angiogenesis. Microvasc. Res. 2006, 71, 218-221. [CrossRef]

61. Ibelli, A.M.G.; Kim, T.K.; Hill, C.C.; Lewis, L.A.; Bakshi, M.; Miller, S.; Porter, L.; Mulenga, A. A Blood Meal-Induced Ixodes scapularis Tick Saliva Serpin Inhibits Trypsin and Thrombin, and Interferes with Platelet Aggregation and Blood Clotting. Int. J. Parasitol. 2014, 44, 369-379. [CrossRef]

62. Islam, M.K.; Tsuji, N.; Miyoshi, T.; Alim, M.A.; Huang, X.; Hatta, T.; Fujisaki, K. The Kunitz-like modulatory protein haemangin is vital for hard tick blood-feeding success. PLoS Pathog. 2009, 5, e1000497. [CrossRef]

63. Karczewski, J.; Endris, R.; Connolly, T.M. Disagregin is a Fibrinogen Receptor Antagonist Lacking the Arg-Gly-Asp Sequence from the Tick, Ornithodoros moubata. J. Biol. Chem. 1994, 269, 6702. [CrossRef]

64. Kim, T.K.; Tirloni, L.; Radulovic, Z.; Lewis, L.; Bakshi, M.; Hill, C.; da Silva Vaz, I.; Logullo, C.; Termignoni, C.; Mulenga, A. Conserved Amblyomma americanum Tick Serpin19, an Inhibitor of Blood Clotting Factors Xa and XIa, Trypsin and Plasmin, Has Anti-haemostatic Functions. Int. J. Parasitol. 2015, 45, 613-627. [CrossRef] [PubMed]

65. Koh, C.Y.; Kazimirova, M.; Trimnell, A.; Takac, P.; Labuda, M.; Nuttall, P.A.; Kini, R.M. Variegin, a Novel Fast and Tight Binding Thrombin Inhibitor from the Tropical Bont Tick. J. Biol. Chem. 2007, 282, 29101-29113. [CrossRef] [PubMed]

66. Koh, C.Y.; Kumar, S.; Kazimirova, M.; Nuttall, P.A.; Radhakrishnan, U.P.; Kim, S.; Jagadeeswaran, P.; Imamura, T.; Mizuguchi, J.; Iwanaga, S.; et al. Crystal Structure of Thrombin in Complex with S-variegin: Insights of a Novel Mechanism of Inhibition and Design of Tunable Thrombin Inhibitors. PLoS ONE 2011, 6, e26367. [CrossRef]

67. Mans, B.J.; Louw, A.I.; Neitz, A.W.H. Savignygrin, a Platelet Aggregation Inhibitor from the Soft Tick Ornithodoros savignyi, Presents the RGD Integrin Recognition Motif on the Kunitz-BPTI Fold. J. Biol. Chem. 2002, 277, 21371-21378. [CrossRef]

68. Mans, B.J.; Ribeiro, J.M.C. Function, Mechanism and Evolution of the Moubatin-clade of Soft Tick Lipocalins. Insect Biochem. Mol. Biol. 2008, 38, 841-852. [CrossRef]

69. Mulenga, A.; Macaluso, K.R.; Simser, J.A.; Azad, A.F. The American Dog Tick, Dermacentor variabilis, Encodes a Functional Histamine Release Factor Homolog. Insect Biochem. Mol. Biol. 2003, 33, 911-919. [CrossRef]

70. Nazareth, R.A.; Tomaz, L.S.; Ortiz-Costa, S.; Atella, G.C.; Ribeiro, J.M.C.; Francischetti, I.M.B.; Monteiro, R.Q. Antithrombotic Properties of Ixolaris, a Potent Inhibitor of the Extrinsic Pathway of the Coagulation Cascade. Thromb. Haemost. 2006, 96, 7-13. [CrossRef] 
71. Nienaber, J.; Gaspar, A.R.M.; Neitz, A.W.H. Savignin, a Potent Thrombin Inhibitor Isolated from the Salivary Glands of the Tick Ornithodoros savignyi (Acari: Argasidae). Exp. Parasitol. 1999, 93, 82-91. [CrossRef] [PubMed]

72. Poole, N.M.; Mamidanna, G.; Smith, R.A.; Coons, L.B.; Cole, J.A. Prostaglandin E(2) in Tick Saliva Regulates Macrophage Cell Migration and Cytokine Profile. Parasit. Vectors 2013, 6, 261. [CrossRef]

73. Ribeiro, J.M.; Makoul, G.T.; Levine, J.; Robinson, D.R.; Spielman, A. Antihemostatic, Antiinflammatory, and Immunosuppressive Properties of the Saliva of a Tick, Ixodes dammini. J. Exp. Med. 1985, 161, 332-344. [CrossRef]

74. Schuijt, T.J.; Bakhtiari, K.; Daffre, S.; DePonte, K.; Wielders, S.J.H.; Marquart, J.A.; Hovius, J.W.; van der Poll, T.; Fikrig, E.; Bunce, M.W.; et al. Factor Xa Activation of Factor V is of Paramount Importance in Initiating the Coagulation System: Lessons from a Tick Salivary Protein. Circulation 2013, 128, 254-266. [CrossRef]

75. Stutzer, C.; Mans, B.J.; Gaspar, A.R.; Neitz, A.W.; Maritz-Olivier, C. Ornithodoros savignyi: Soft Tick Apyrase Belongs to the 5'-nucleotidase Family. Exp. Parasitol. 2009, 122, 318-327. [CrossRef] [PubMed]

76. van de Locht, A.; Stubbs, M.T.; Bode, W.; Friedrich, T.; Bollschweiler, C.; Höffken, W.; Huber, R. The Ornithodorin-thrombin Crystal Structure, a Key to the TAP enigma? EMBO J. 1996, 15, 6011-6017. [CrossRef]

77. Wang, X.; Coons, L.B.; Taylor, D.B.; Stevens, S.E.; Gartner, T.K. Variabilin, a Novel RGD-containing Antagonist of Glycoprotein IIb-IIIa and Platelet Aggregation Inhibitor from the Hard Tick Dermacentor variabilis. J. Biol. Chem. 1996, 271, 17785-17790. [CrossRef]

78. Waxman, L.; Connolly, T. Isolation of an Inhibitor Selective for Collagen-stimulated Platelet Aggregation from the Soft Tick Ornithodoros moubata. J. Biol. Chem. 1993, 268, 5445. [CrossRef]

79. Waxman, L.; Smith, D.; Arcuri, K.; Vlasuk, G. Tick Anticoagulant Peptide (TAP) is a Novel Inhibitor of Blood Coagulation Factor Xa. Science 1990, 248, 593-596. [CrossRef]

80. Xu, T.; Lew-Tabor, A.; Rodriguez-Valle, M. Effective Inhibition of Thrombin by Rhipicephalus microplus Serpin-15 (RmS-15) Obtained in the Yeast Pichia pastoris. Ticks Tick Borne Diseas. 2016, 7, 180-187. [CrossRef]

81. Štibrániová, I.; BartÍKovÁ, P.; Holíková, V.; Kazimírová, M. Deciphering Biological Processes at the Tick-Host Interface Opens New Strategies for Treatment of Human Diseases. Front. Physiol. 2019, 10. [CrossRef] [PubMed]

82. Chmelař, J.; Kotál, J.; Karim, S.; Kopacek, P.; Francischetti, I.M.B.; Pedra, J.H.F.; Kotsyfakis, M. Sialomes and Mialomes: A SystemsBiology View of Tick Tissues and Tick-Host Interactions. Trend. Parasitol. 2016, 32, 242-254. [CrossRef] [PubMed]

83. Kotál, J.; Langhansová, H.; Lieskovská, J.; Andersen, J.F.; Francischetti, I.M.B.; Chavakis, T.; Kopecký, J.; Pedra, J.H.F.; Kotsyfakis, M.; Chmelař, J. Modulation of Host Immunity by Tick Saliva. J. Proteom. 2015, 128, 58-68. [CrossRef] [PubMed]

84. Valenzuela, J.G. Exploring Tick Saliva: From Biochemistry to 'Sialomes' and Functional Genomics. Parasitology 2004, 129, S83-S94. [CrossRef] [PubMed]

85. Anguita, J.; Ramamoorthi, N.; Hovius, J.W.R.; Das, S.; Thomas, V.; Persinski, R.; Conze, D.; Askenase, P.W.; Rincón, M.; Kantor, F.S.; et al. Salp15, an Ixodes scapularis Salivary Protein, Inhibits CD4+ T Cell Activation. Immunity 2002, 16, 849-859. [CrossRef]

86. Beaufays, J.; Adam, B.; Menten-Dedoyart, C.; Fievez, L.; Grosjean, A.; Decrem, Y.; Prévôt, P.-P.; Santini, S.; Brasseur, R.; Brossard, M.; et al. Ir-LBP, an Ixodes ricinus Tick Salivary LTB4-Binding Lipocalin, Interferes with Host Neutrophil Function. PLoS ONE 2008, 3, e3987. [CrossRef] [PubMed]

87. Blisnick, A.A.; Šimo, L.; Grillon, C.; Fasani, F.; Brûlé, S.; Le Bonniec, B.; Prina, E.; Marsot, M.; Relmy, A.; Blaise-Boisseau, S.; et al. The Immunomodulatory Effect of IrSPI, a Tick Salivary Gland Serine Protease Inhibitor Involved in Ixodes ricinus Tick Feeding. Vaccines 2019, 7, 148. [CrossRef]

88. Daix, V.; Schroeder, H.; Praet, N.; Georgin, J.P.; Chiappino, I.; Gillet, L.; Fays, K.; Decrem, Y.; Leboulle, G.; Godfroid, E.; et al. Ixodes Ticks Belonging to the Ixodes ricinus Complex Encode a Family of Anticomplement Proteins. Insect Mol. Biol. 2007, 16, 155-166. [CrossRef]

89. Esteves, E.; Bizzarro, B.; Costa, F.B.; Ramírez-Hernández, A.; Peti, A.P.F.; Cataneo, A.H.D.; Wowk, P.F.; Timóteo, R.P.; Labruna, M.B.; Silva Junior, P.I.; et al. Amblyomma sculptum Salivary PGE(2) Modulates the Dendritic Cell-Rickettsia rickettsii Interactions in vitro and in vivo. Front. Immunol. 2019, 10, 118. [CrossRef]

90. Garg, R.; Juncadella, I.J.; Ramamoorthi, N.; Ashish; Ananthanarayanan, S.K.; Thomas, V.; Rincón, M.; Krueger, J.K.; Fikrig, E.; Yengo, C.M.; et al. Cutting Edge: CD4 is the Receptor for the Tick Saliva Immunosuppressor, Salp15. J. Immunol. 2006, 177, 6579-6583. [CrossRef]

91. Hannier, S.; Liversidge, J.; Sternberg, J.M.; Bowman, A.S. Characterization of the B-cell Inhibitory Protein Factor in Ixodes ricinus Tick Saliva: A Potential Role in Enhanced Borrelia burgdoferi Transmission. Immunology 2004, 113, 401-408. [CrossRef] [PubMed]

92. Hourcade, D.E.; Akk, A.M.; Mitchell, L.M.; Zhou, H.-f.; Hauhart, R.; Pham, C.T.N. Anti-Complement Activity of the Ixodes scapularis Salivary Protein Salp20. Mol. Immunol. 2016, 69, 62-69. [CrossRef]

93. Hovius, J.W.R.; de Jong, M.A.W.P.; den Dunnen, J.; Litjens, M.; Fikrig, E.; van der Poll, T.; Gringhuis, S.I.; Geijtenbeek, T.B.H. Salp15 Binding to DC-SIGN Inhibits Cytokine Expression by Impairing both Nucleosome Remodeling and mRNA Stabilization. PLoS Pathog. 2008, 4, e31. [CrossRef]

94. Inokuma, H.; Kemp, D.H.; Willadsen, P. Prostaglandin E2 Production by the Cattle Tick (Boophilus microplus) into Feeding Sites and its Effect on the Response of Bovine Mononuclear Cells to Mitogen. Vet. Parasitol. 1994, 53, 293-299. [CrossRef] 
95. Katharine, R.T.; Christopher, E.; Aravinda, M.d.S. A Novel Mechanism of Complement Inhibition Unmasked by a Tick Salivary Protein That Binds to Properdin. J. Immunol. 2008, 180, 3964-3968. [CrossRef]

96. Kotál, J.; Stergiou, N.; Buša, M.; Chlastáková, A.; Beránková, Z.; Řezáčová, P.; Langhansová, H.; Schwarz, A.; Calvo, E.; Kopecký, J.; et al. The Structure and Function of Iristatin, a Novel Immunosuppressive Tick Salivary Cystatin. Cell. Mol. Life Sci. 2019, 76, 2003-2013. [CrossRef]

97. Leboulle, G.; Crippa, M.; Decrem, Y.; Mejri, N.; Brossard, M.; Bollen, A.; Godfroid, E. Characterization of a Novel Salivary Immunosuppressive Protein from Ixodes ricinus ticks. J. Biol. Chem. 2002, 277. [CrossRef] [PubMed]

98. Liu, J.; Renneker, S.; Beyer, D.; Kullmann, B.; Seitzer, U.; Ahmed, J.; Bakheit, M.A. Identification and Partial Characterization of a Salp15 Homolog from Ixodes ricinus. Ticks Tick Borne Dis. 2014, 5, 318-322. [CrossRef] [PubMed]

99. Ramamoorthi, N.; Narasimhan, S.; Pal, U.; Bao, F.; Yang, X.F.; Fish, D.; Anguita, J.; Norgard, M.V.; Kantor, F.S.; Anderson, J.F.; et al. The Lyme Disease Agent Exploits a Tick Protein to Infect the Mammalian Host. Nature 2005, 436, 573-577. [CrossRef] [PubMed]

100. Sá-Nunes, A.; Bafica, A.; Lucas, D.A.; Conrads, T.P.; Veenstra, T.D.; Andersen, J.F.; Mather, T.N.; Ribeiro, J.M.; Francischetti, I.M. Prostaglandin E2 is a Major Inhibitor of Dendritic Cell Maturation and Function in Ixodes scapularis Saliva. J. Immunol. 2007, 179, 1497-1505. [CrossRef]

101. Sun, T.; Wang, F.; Pan, W.; Wu, Q.; Wang, J.; Dai, J. An Immunosuppressive Tick Salivary Gland Protein DsCystatin Interferes With Toll-Like Receptor Signaling by Downregulating TRAF6. Front. Immunol. 2018, 9. [CrossRef] [PubMed]

102. Tian, Y.; Chen, W.; Mo, G.; Chen, R.; Fang, M.; Yedid, G.; Yan, X. An Immunosuppressant Peptide from the Hard Tick Amblyomma variegatum. Toxins 2016, 8, 133. [CrossRef]

103. Tyson, K.; Elkins, C.; Patterson, H.; Fikrig, E.; Silva, A. Biochemical and Functional Characterization of Salp20, an Ixodes scapularis Tick Salivary Protein that Inhibits the Complement Pathway. Insect Mol. Biol. 2007, 16, 469-479. [CrossRef]

104. Valenzuela, J.G.; Charlab, R.; Mather, T.N.; Ribeiro, J.M. Purification, Cloning, and Expression of a Novel Salivary Anticomplement Protein from the Tick, Ixodes scapularis. J. Biol. Chem. 2000, 275. [CrossRef]

105. Yu, D.; Liang, J.; Yu, H.; Wu, H.; Xu, C.; Liu, J.; Lai, R. A Tick B-cell Inhibitory Protein from Salivary Glands of the Hard Tick, Hyalomma asiaticum asiaticum. Biochem. Biophys. Res. Comm. 2006, 343, 585-590. [CrossRef]

106. Ricklin, D.; Hajishengallis, G.; Yang, K.; Lambris, J.D. Complement: A Key System for Immune Surveillance and Homeostasis. Nat. Immunol. 2010, 11. [CrossRef]

107. Jason, R.D.; Wen-Chao, S. Complement and its Role in Innate and Adaptive Immune Responses. Cell Res. 2010, 20 , 34-50. [CrossRef]

108. Lubbers, R.; van, E.M.F.; van, K.C.; La, T. Production of Complement Components by Cells of the Immune System. Clin. Exp. Immunol. 2017, 188. [CrossRef] [PubMed]

109. Reis, E.S.; Mastellos, D.C.; Hajishengallis, G.; Lambris, J.D. New Insights Into the Immune Functions of Complement. Nat. Rev. Immunol. 2019, 19. [CrossRef]

110. Dulipati, V.; Meri, S.; Panelius, J. Complement Evasion Strategies of Borrelia burgdorferi sensu lato. FEBS Lett. 2020, 594, 2645-2656. [CrossRef] [PubMed]

111. Schuijt, T.J.; Coumou, J.; Narasimhan, S.; Dai, J.; Deponte, K.; Wouters, D.; Brouwer, M.; Oei, A.; Roelofs, J.J.; van, D.A.P.; et al. A Tick Mannose-binding Lectin Inhibitor Interferes with the Vertebrate Complement Cascade to Enhance Transmission of the Lyme Disease Agent. Cell Host Microbe 2011, 10. [CrossRef]

112. Wagemakers, A.; Coumou, J.; Schuijt, T.J.; Oei, A.; Nijhof, A.M.; van 't Veer, C.; van der Poll, T.; Bins, A.D.; Hovius, J.W. An Ixodes ricinus Tick Salivary Lectin Pathway Inhibitor Protects Borrelia burgdorferi sensu lato from Human Complement. Vector Borne Zoonotic Dis. 2016, 16, 223-228. [CrossRef]

113. Kirchner, S.; Lei, V.; MacLeod, A.S. The Cutaneous Wound Innate Immunological Microenvironment. Int. J. Mol. Sci. 2020, 21, 8748. [CrossRef]

114. Kabashima, K.; Honda, T.; Ginhoux, F.; Egawa, G. The Immunological Anatomy of the Skin. Nat. Rev. Immunol. 2019, 19, 19-30. [CrossRef]

115. Brossard, M.; Wikel, S.K. Immunology of Interactions Between Ticks and Hosts. Med. Vet. Entomol. 1997, 11, 270-276. [CrossRef]

116. Wikel, S.K. Host Immunity to Ticks. Ann. Rev. Entomol. 1996, 41, 1-22. [CrossRef]

117. Karasuyama, H.; Miyake, K.; Yoshikawa, S. Immunobiology of Acquired Resistance to Ticks. Front. Immunol. 2020, 11, 601504. [CrossRef] [PubMed]

118. Allen, J.R. Immunology of Interactions Between Ticks and Laboratory Animals. Exp. App. Acarol. 1989, 7, 5-13. [CrossRef]

119. Trager, W. Acquired Immunity to Ticks. J. Parasit. 1939, 25, 57-81. [CrossRef]

120. Lynn, G.E.; Diktas, H.; DePonte, K.; Fikrig, E. Naturally Acquired Resistance to Ixodes scapularis Elicits Partial Immunity against Other Tick Vectors in a Laboratory Host. Am. J. Trop. Med. Hyg. 2021, 104, 175-183. [CrossRef] [PubMed]

121. Fang, R.; Ismail, N.; Soong, L.; Popov, V.L.; Whitworth, T.; Bouyer, D.H.; Walker, D.H. Differential interaction of dendritic cells with Rickettsia conorii: Impact on host susceptibility to murine spotted fever rickettsiosis. Infect Immun 2007, 75, 3112-3123. [CrossRef]

122. Zeidner, N.S.; Schneider, B.S.; Rutherford, J.S.; Dolan, M.C. Suppression of Th2 Cytokines Reduces Tick-transmitted Borrelia burgdorferi Load in Mice. J. Parasitol. 2008, 94, 767-769. [CrossRef] [PubMed] 
123. Hovius, J.W.; Schuijt, T.J.; Groot, K.A.; Roelofs, J.J.T.H.; Oei, G.A.; Marquart, J.A.; Beer, R.; van 't Veer, C.; van der Poll, T.; Ramamoorthi, N.; et al. Preferential Protection of Borrelia burgdorferi Sensu Stricto by a Salp15 Homologue in Ixodes ricinus Saliva. J. Infect. Dis. 2008, 198, 1189-1197. [CrossRef] [PubMed]

124. Marchal, C.; Schramm, F.; Kern, A.; Luft, B.J.; Yang, X.; Schuijt, T.; Hovius, J.; Jaulhac, B.; Boulanger, N. Antialarmin Effect of Tick Saliva during the Transmission of Lyme Disease. Infect. Immun. 2010, 79, 774-785. [CrossRef] [PubMed]

125. Sukumaran, B.; Narasimhan, S.; Anderson, J.F.; DePonte, K.; Marcantonio, N.; Krishnan, M.N.; Fish, D.; Telford, S.R.; Kantor, F.S.; Fikrig, E. An Ixodes scapularis Protein Required for Survival of Anaplasma phagocytophilum in Tick Salivary Glands. J. Exp. Med. 2006, 203, 1507-1517. [CrossRef]

126. Hiroshi, U.; Hiroshi, T.; Tetsuya, K.; Masutaka, F. Cytokines and Chemokines in the Epidermis. J. Dermatol. Sci. 2000, 24, S29-S38. [CrossRef]

127. Larry, C.B.; John, W.S. 2. Cytokines and Chemokines. J. Allerg. Clin. Immunol. 2003, 111, S460-S475. [CrossRef]

128. Strle, K.; Sulka, K.B.; Pianta, A.; Crowley, J.T.; Arvikar, S.L.; Anselmo, A.; Sadreyev, R.; Steere, A.C. T-Helper 17 Cell Cytokine Responses in Lyme Disease Correlate With Borrelia burgdorferi Antibodies During Early Infection and With Autoantibodies Late in the Illness in Patients With Antibiotic-Refractory Lyme Arthritis. Clin. Infect. Dis. 2017, 64, 930-938. [CrossRef]

129. Storan, E.R.; O'Gorman, S.M.; McDonald, I.D.; Steinhoff, M. Role of Cytokines and Chemokines in Itch. Handb. Exp. Pharmacol. 2015, 226, 163-176. [CrossRef] [PubMed]

130. Clemetson, K.J.; Clemetson, J.M.; Proudfoot, A.E.; Power, C.A.; Baggiolini, M.; Wells, T.N. Functional Expression of CCR1, CCR3, CCR4, and CXCR4 Chemokine Receptors on Human Platelets. Blood 2000, 96, 4046-4054. [CrossRef]

131. Akdis, C.A.; Blaser, K. Histamine in the Immune Regulation of Allergic Inflammation. J. Allergy Clin. Immunol. 2003, 112, 15-22. [CrossRef]

132. Valenzuela, J.G.; Francischetti, I.M.; Pham, V.M.; Garfield, M.K.; Mather, T.N.; Ribeiro, J.M. Exploring the Sialome of the Tick Ixodes scapularis. J. Exp. Biol. 2002, 205, 2843-2864. [PubMed]

133. Ribeiro, J.M.C.; Mans, B.J. TickSialoFam (TSFam): A Database That Helps to Classify Tick Salivary Proteins, a Review on Tick Salivary Protein Function and Evolution, With Considerations on the Tick Sialome Switching Phenomenon. Front. Cell. Infect. Microbiol. 2020, 10, 374. [CrossRef] [PubMed]

134. Ayllón, N.; Villar, M.; Galindo, R.C.; Kocan, K.M.; Šíma, R.; López, J.A.; Vázquez, J.; Alberdi, P.; Cabezas-Cruz, A.; Kopáček, P.; et al. Systems Biology of Tissue-specific Response to Anaplasma phagocytophilum Reveals Differentiated Apoptosis in the Tick Vector Ixodes scapularis. PLoS Genet. 2015, 11, e1005120. [CrossRef]

135. Ribeiro, J.M.C.; Alarcon-Chaidez, F.; Francischetti, I.M.B.; Mans, B.J.; Mather, T.N.; Valenzuela, J.G.; Wikel, S.K. An Annotated Catalog of Salivary Gland Transcripts from Ixodes scapularis ticks. Insect Biochem. Mol. Biol. 2006, 36, 111-129. [CrossRef]

136. Cotté, V.; Sabatier, L.; Schnell, G.; Carmi-Leroy, A.; Rousselle, J.-C.; Arsène-Ploetze, F.; Malandrin, L.; Sertour, N.; Namane, A.; Ferquel, E.; et al. Differential Expression of Ixodes ricinus Salivary Gland Proteins in the Presence of the Borrelia burgdorferi sensu lato Complex. J. Proteom. 2014, 96, 29-43. [CrossRef]

137. Trentelman, J.J.A.; Sima, R.; Krezdorn, N.; Tomás-Cortázar, J.; Barriales, D.; Takumi, K.; Butler, J.M.; Sprong, H.; Klouwens, M.J.; Urbanova, V.; et al. A Combined Transcriptomic Approach to Identify Candidates for an Anti-tick Vaccine Blocking B. afzelii transmission. Sci. Rep. 2020, 10, 20061. [CrossRef] [PubMed]

138. Valdés, J.J.; Cabezas-Cruz, A.; Sima, R.; Butterill, P.T.; Růžek, D.; Nuttall, P.A. Substrate Prediction of Ixodes ricinus Salivary Lipocalins Differentially Expressed During Borrelia afzelii Infection. Sci. Rep. 2016, 6, 32372. [CrossRef] [PubMed]

139. Mondanelli, G.; Volpi, C. The Double Life of Serotonin Metabolites: In the Mood for Joining Neuronal and Immune Systems. Curr. Opin. Immunol. 2020, 70, 1-6. [CrossRef]

140. Hart, C.E.; Ribeiro, J.M.; Kazimirova, M.; Thangamani, S. Tick-Borne Encephalitis Virus Infection Alters the Sialome of Ixodes ricinus Ticks During the Earliest Stages of Feeding. Front. Cell. Infect. Microbiol. 2020, 10. [CrossRef]

141. Labuda, M.; Trimnell, A.R.; Licková, M.; Kazimírová, M.; Davies, G.M.; Lissina, O.; Hails, R.S.; Nuttall, P.A. An Antivector Vaccine Protects Against a Lethal Vector-borne Pathogen. PLoS Pathog. 2006, 2, e27. [CrossRef]

142. Hermance, M.E.; Widen, S.G.; Wood, T.G.; Thangamani, S. Ixodes scapularis Salivary Gland microRNAs are Differentially Expressed During Powassan Virus Transmission. Sci. Rep. 2019, 9, 13110. [CrossRef] [PubMed]

143. Hackenberg, M.; Langenberger, D.; Schwarz, A.; Erhart, J.; Kotsyfakis, M. In silico Target Network Analysis of de Novo-Discovered, Tick Saliva-specific microRNAs Reveals Important Combinatorial Effects in their Interference with Vertebrate Host Physiology. RNA 2017, 23, 1259-1269. [CrossRef]

144. Malik, M.I.; Nawaz, M.; Hassan, I.A.; Zhang, H.; Gong, H.; Cao, J.; Zhou, Y.; Zhou, J. A microRNA Profile of Saliva and Role of miR-375 in Haemaphysalis longicornis (Ixodida: Ixodidae). Parasit. Vectors 2019, 12, 68. [CrossRef]

145. Nawaz, M.; Malik, M.I.; Zhang, H.; Gebremedhin, M.B.; Cao, J.; Zhou, Y.; Zhou, J. miRNA Profile of Extracellular Vesicles Isolated from Saliva of Haemaphysalis longicornis tick. Acta Trop. 2020, 212, 105718. [CrossRef] [PubMed]

146. Nawaz, M.; Malik, M.I.; Zhang, H.; Hassan, I.A.; Cao, J.; Zhou, Y.; Hameed, M.; Hussain Kuthu, Z.; Zhou, J. Proteomic Analysis of Exosome-Like Vesicles Isolated From Saliva of the Tick Haemaphysalis longicornis. Front. Cell. Infect. Microbiol. 2020, 10, 542319. [CrossRef]

147. Zhou, W.; Tahir, F.; Wang, J.C.; Woodson, M.; Sherman, M.B.; Karim, S.; Neelakanta, G.; Sultana, H. Discovery of Exosomes From Tick Saliva and Salivary Glands Reveals Therapeutic Roles for CXCL12 and IL-8 in Wound Healing at the Tick-Human Skin Interface. Front. Cell. Dev. Biol. 2020, 8, 554. [CrossRef] [PubMed] 
148. Chávez, A.S.O.; O’Neal, A.J.; Santambrogio, L.; Kotsyfakis, M.; Pedra, J.H.F. Message in a Vesicle-Trans-kingdom Intercommunication at the Vector-host Interface. J. Cell. Sci. 2019, 132. [CrossRef] [PubMed]

149. Zhou, W.; Woodson, M.; Neupane, B.; Bai, F.; Sherman, M.B.; Choi, K.H.; Neelakanta, G.; Sultana, H. Exosomes Serve as Novel Modes of Tick-borne Flavivirus Transmission from Arthropod to Human cells and Facilitates Dissemination of Viral RNA and Proteins to the Vertebrate Neuronal Cells. PLoS Pathog. 2018, 14, e1006764. [CrossRef] 